\title{
The Effects of Age at Arrival and Enclave Schools on the Academic Performance of Immigrant Children
}

\author{
Kalena E. Cortes ${ }^{*}$ \\ Population Studies Center \\ University of Pennsylvania \\ kcortes@sas.upenn.edu
}

\begin{abstract}
In this paper, I analyze the relationship between age at arrival and immigrant receiving high schools (i.e., enclave schools) on the academic performance of immigrant children using data from the Children of Immigrants Longitudinal Study (CILS) 1992-1993 and the Common Core of Data (CCD) 1992-1993. The CILS was conducted in two major immigrant-receiving cities in the United States-San Diego and Miami. I classify the public schools in the CILS universe as enclave schools based on the fraction of children in the school sample who were born abroad. I find that the test score gap between US-born and first generation immigrant children decreases the longer immigrant children reside in the US. Overall, the findings in this paper suggest that immigrant children in enclave schools perform as well as immigrant children that attend non-enclave schools.
\end{abstract}

JEL Classifications: I20, J00, J13

Keywords: Human Capital, Rate of Return, and School Choice.

"Population Studies Center, 3718 Locust Walk, 239 McNeil Bldg., University of Pennsylvania, Philadelphia, PA 19104-6298. I would like to thank David Card for all his encouragement and most valued advice. Also, I would like to thank Steven Raphael for his comments and support. I also thank Alan B. Krueger, Ronald D. Lee, Marta Tienda, Ruben Rumbaut and the labor lunch participants at UC Berkeley for their comments. Research results, conclusions, and all errors are naturally my own. 


\section{Introduction}

The majority of research on immigrant adaptation in the United States has focused solely on immigrants who are of working age and in the labor market (Chiswick 1978; Borjas 1985, 1987,1995a; Friedberg 1993; Friedberg and Hunt 1995; Shoeni 1996; Card, DiNardo, and Estes 1998). Other studies have tried to document the potential adverse effects that immigrants may have on the wages, labor supply, and labor demand of native-born workers (Borjas, Freeman, and Katz 1992; Card 1990, 2001; Altonji and Card 1991; Grossman 1982; Shoeni 1996). Very few studies, however, have paid attention to the adaptation of their children. Since children of immigrants make up 20 percent of the nation's student population (Urban Institute 2000), the assimilation of immigrant children is clearly an important issue. Most immigrant youths will remain in the U.S., and their success later in life is presumably determined by their adaptation to the U.S. school system. For instance, low-test scores of youths are associated with negative labor market outcomes as adults (Currie and Thomas 1999; Murnane, Willet, and Levy 1995).

In this paper, I explore the relationship between age at arrival and attendance at an immigrant receiving high schools (i.e., enclave schools) on the academic performance of immigrant children using data from the Children of Immigrants Longitudinal Study (CILS) 1992-1993 combined with the Common Core of Data (CCD) 1992-1993. The CILS data set contains detailed information on academic performance, school characteristics, and parents of immigrant children in two major immigrant-receiving cities in the United States-San Diego and Miami. ${ }^{1}$ In addition, it is possible to match each public high school in the CILS with the CCD and obtain information on school characteristics such as the pupil/teacher ratio.

\footnotetext{
${ }^{1}$ The CILS data set contains information on both first and second generation children of immigrant parents. In the analysis I distinguish between these two groups of children, more specifically, the first generation are referred to as "immigrant children" and the second generation are referred to as "US-born children."
} 
This study contributes to the literature in two ways. First, I examine the academic performance of immigrant children relative to US-born children by analyzing their test scores from two widely used cognitive tests: the English reading vocabulary and comprehension subtest of the Abbreviated Stanford Achievement Test (ASAT-READING) and the mathematics subtest of the Abbreviated Stanford Achievement Test (ASAT-MATH). Secondly, I compare enclave schools to non-enclave schools, and analyze how these two different academic settings could potentially slow-down or speed-up the academic performance of immigrant children. Since immigrant parents tend to settle in predominantly immigrant and low-income communities, one might expect the academic performance of their children to differ in these two school settings.

Overall, the findings in this paper suggest that immigrant children that arrive in the US before their schooling starts perform as well as those that were born in the US to immigrant parents, regardless of whether they attend enclave schools. I find that the test score gap between US-born and immigrant children decreases the longer immigrant children reside in the US. In fact, with more than 10 years of US residence, immigrant children perform as well as their USborn counterparts.

Immigrant children in enclave schools perform as well as immigrant children that attend nonenclave schools for both San Diego and Miami samples. Although immigrant children who attend non-enclave schools in San Diego appear to score higher on both reading and math the difference is not statistically significant. For immigrant children in the Miami sample, there is a slight enclave school effect on both reading and math test, however, this effect is very small and marginally significant.

In addition, I perform a semi-parametric estimation, most commonly known as propensity score matching technique, to counter the non-randomness of the sample. This alternative 
procedure attempts to mediate the potential bias in the sample due to possible selection into enclave schools. The propensity score estimation attains the same qualitative conclusions.

The remainder of this paper is organized as follows. Section 2 provides a literature review. Section 3 discusses the data and presents some sample characteristics. The empirical specifications are described in Section 4. Section 5 presents the main results of this paper. Section 6 concludes.

\section{Literature Review}

\section{Second Generation Studies}

There is relatively little research on how immigrant children fare in the US school system. A study by Portes and MacLeod (1999) looks at how human capital, social capital, and modes of incorporation affect the educational achievement of the second generation. ${ }^{2}$ They find that after controlling for parental education, language, and skill endowment (i.e., human capital), and family structure (i.e., social networks), differences in educational achievement across nationality groups largely disappear. However, after controlling for group differences in the context of reception and immigration history, initial nationality effects remain.

A study by Betts (1998) outlines some possible costs inflicted on US-born children that attend immigrant receiving high schools. In particular, there is the competition between immigrant and US-born children for school resources. Given that young immigrants are not perfectly acculturated to US public high schools, they often lack English skills. If separate classes are made available for immigrant children, such as Limited English Proficiency (LEP) classes, there could be a reduction in school resources available to US-born children. On the

\footnotetext{
${ }^{2}$ This article refers to second generation as children of immigrants.
} 
other hand, Betts notes that immigrant receiving high schools do in fact get extra funding from the government to aid them. ${ }^{3}$

In addition, most of the literature on intergenerational assimilation of the second generation has mainly focused on the earnings profiles of adult children of immigrants (Borjas 1992, 1995b; Card, DiNardo, and Estes 1998). An analogous measure of adaptation for school-aged children of immigrants is their academic performance relative to native-born children. However, very little research has focused on the children of immigrants while they are in school. Perhaps the main obstacle to studying children of immigrants or immigrant children during their schooling years is the lack of adequate data.

\section{School Outcomes and Labor Market Performance}

Since education is a very important predictor of future earnings, this paper will focus on an earlier stage in the lives of immigrants-during their early human capital formative years when they are attending public schools. Past studies have found that lower test scores while in school may have implications for future labor market success. Currie and Thomas (1999) find that math scores at both ages seven and fourteen are positively related to adult labor market outcomes such as earnings. In another study, Murnane et al. (1995) find that basic math skills for young adults increased over the 1980's, and they also show that basic cognitive skills have a larger impact on wages for 24 year-old men and women in 1986 than in 1978. Their findings suggest that as technology continues to alter the work place, returns to math skills will also continue to increase. For immigrant children, the labor market implications of school

\footnotetext{
${ }^{3}$ In 1984 Congress passed the "Emergency Immigrant Education Act" in order to provide funding to schools districts that had a large fraction of immigrant students. Refer to US Government Printing Office (1984) for the original text of the bill passed.
} 
performance may be even stronger. Not only do they have to acclimatize to their new surroundings, they also have to master the language of their new home environment.

\section{School Resources and Academic Performance}

Although there exists a large literature that studies the relationship between school inputs and the academic performance of students, the literature is far from reaching a consensus (Card and Krueger 1992; Hanushek, Rivkin, and Taylor 1996; Hanushek 1997). One might expect school inputs to be positively related to student academic performance. However, existing studies show a wide range of empirical results-positive and negative, significant and insignificant (Hanushek 1997). A study by Card and Krueger (1992) estimates the effect of pupil/teacher ratios and teachers' salaries on the rate of return to education for men born between 1920 and 1950, observed in the 1980 Census. Controlling for state of birth, state of residence effects, and differences in returns to education between regional labor markets, they find a large negative and significant effect of pupil/teacher ratios on the return to education.

Other studies by Hanushek et al. (1996) and Hanushek (1997) have challenged aspects of the Card and Krueger analysis. Hanushek et al. show that when school resources are measured at the school-level, the relationships with school performance tend to be insignificant and that the likelihood of a significant relationship increases with higher levels of aggregation. They argue that school-level measures of school resources give better estimates of the effects of these resources on student outcomes. Hanushek et al. replicate the Card and Krueger results with the 1970, 1980, and 1990 Censuses, and they stress the importance of allowing for non-linear returns to education when estimating the impact of school resources. They find that school quality 
effects are weak for those with exactly 12 years of schooling, but that there exist strong school quality effects for those who attend college.

Other empirical findings suggest that students who attend inner-city schools have very different wage outcomes compared to students who attend suburban schools. Sexton and Nickel (1992) find that students who attend a central city high school have between four to ten percent lower earnings than their suburban counterparts.

Given the array of results surrounding school inputs and student performance, I have included in the analysis one of the most widely used measures of school quality - the pupil/teacher ratio. Since immigrant children are more likely to attend public schools, it seems warranted to control for this factor in the analysis.

Past studies have documented the importance of school resources on student academic performance, and in turn the important link between academic performance and future labor market outcomes. However, no one has really studied these issues for immigrant children. This paper will contribute to the literature by analyzing the relationship between age at arrival and attendance at an immigrant receiving schools on the academic performance of immigrant children in the United States.

\section{Data Sources, Sample Selection, and Summary Statistics}

\section{A Data Sources}

The data for this analysis comes from the first wave of the Children of Immigrant

Longitudinal Study (CILS), which gathered detailed information on over 5,200 second 
generation children in the spring of $1992 .{ }^{4}$ This data set constitutes a rich source of information on academic performance, school characteristics, parental information, educational and occupational aspirations of the immigrant child, and subjective measures of personal experience (e.g., discrimination, peer pressure, family conflict, self worth, etc.). The CILS survey was conducted in two key immigrant receiving-cities: San Diego and Miami. The children in this study consist of students that were enrolled in eighth and ninth grade at the time of the survey and were from the San Diego Unified School District (17 schools); and the Dade and Broward County Unified School Districts (23 schools). ${ }^{5}$

In addition to the CILS data, I have used the Common Core of Data (CCD) 1992-1993 to match each public high school from CILS with its corresponding pupil/teacher ratio. The CCD consist of four surveys completed annually by state education departments to report on almost all US public elementary and secondary schools, local education agencies, and state education agencies. I use only one of the four surveys available--the Public School Universe. This component provides information on all public elementary and secondary schools in operation during a school year including school location and type, enrollment by grade, student characteristics, and the number of classroom teachers.

\section{B Sample Selection and Construction}

Students were eligible to participate in the CILS study if they were US-born and had at least one immigrant parent (henceforth, US-born children), or if they were foreign-born and

\footnotetext{
${ }^{4}$ The CILS data collection was supervised by Alejandro Portes (Miami) and Ruben Rumbaut (San Diego). The second wave of this survey was conducted in 1995-1996 and collected information on the same children now graduating from high school. Wave three is currently being collected on the same children and mainly focuses on their labor market experience, specifically on their transition into the labor force.

${ }^{5}$ In the estimation I only include public high schools, which make up the majority of the sample. The original survey sampled 40 public high schools and just two private high schools.
} 
immigrated to the US before the age of ten (henceforth, immigrant children). In order to avoid the potential bias of differential dropout rates among ethnic groups at the senior high school level, the sample was drawn from middle, junior high, and senior high school levels at which dropout rates are still relatively low — specifically, eighth and ninth grade. Within schools, eligible students were sampled with probability equal to one. ${ }^{6}$ This yielded a final sample where immigrant nationalities are represented with probabilities proportional to their size in the targeted schools. In addition an over-sample representing 25 percent of the total was reserved for smaller nationality groups.

I classified the public schools in the CILS universe as enclave schools based on the fraction of children in the school sample who were born abroad. More precisely, individual schools that had greater than 25 percent of the interviewed school sample born abroad were classified as immigrant receiving schools.

\section{C Summary Statistics}

The children interviewed in these middle, junior high, and senior high schools are representative of today's immigrant flows to the US. Recent immigrant flows to the US originate predominantly from Mexico, Central America, South America, East Asia, South Asia, and Southeast Asia (South East Asians are more likely to be from refugee-sending countries). ${ }^{7}$

Table 1 presents the pooled sample sizes of US-born and immigrant children in Miami and San Diego public high schools by nationality and gender. The sample includes 2658 girls

\footnotetext{
${ }^{6}$ Eligible students are those who received parental consent. The process consisted of students taking the required form home, asking a parent to complete and sign it, and then returning the form to the school. The overall response rate was 60 percent, but individual schools varied greatly in their response rates. At no instance did the response rate fall below 46 percent of eligible students, and in several schools it reached as high as 72 percent.

${ }^{7}$ See Cortes (2002) for detailed discussion on this point.
} 
and 2397 boys. ${ }^{8}$ Long-standing immigrant settlement patterns are evident in this table. The Miami sample consists mainly of Cubans, Central Americans (i.e., Nicaraguans, Salvadorians, Guatemalans, Hondurans, Costa Ricans, and Panamanians), Caribbeans (i.e., Dominicans, Jamaicans, and West Indians), South Americans (i.e., Colombians, Argentineans, Chileans, Ecuadorians, Peruvians, and Venezuelans). By comparison, the San Diego consists of Mexicans, Filipinos, East and South Asians (i.e., Chinese, Taiwanese, Japanese, Koreans, Indians, and Pakistanis), and Southeast Asians (i.e., Vietnamese, Laotians, Cambodians, and Hmongs). The category "Others" in Table 1 refers to smaller nationality groups originating from the Middle East, Africa, Europe, and Canada.

The CILS survey includes several indicators of academic progress and achievement such as the number of hours dedicated to weekly school homework and the national percentile rank scores based on the reading and math subtest of the Abbreviated Stanford Achievement Test (ASAT-READING and ASAT-MATH), which were collected from school records. I also construct a measure of "years behind" using age and current grade, designed to capture the number of years a student was held back in school. ${ }^{9} \quad$ Table 2 shows the mean differences between the US-born and immigrant children of the following variables: weekly homework hours, ASAT-READING percentile scores, ASAT-MATH percentile scores, and years behind. We observe that for each of these variables there exists a statistically significant difference between US-born and immigrant children. Looking at the pooled sample of girls and boys, we see that US-born children study 0.15 of an hour less than immigrant children. However, US-

\footnotetext{
${ }^{8}$ The West Indian sample has an over sample of girls compared to boys.

${ }^{9}$ The variable years behind was constructed in the following way: years behind = (Age-Grade-5). This measure is based on the assumption that a child starts the first grade at age five. A better measure would have used the exact birth month for each child instead of the variable age because children born later in the year are always younger. However, this information was not collected in the survey. In lieu of this, I have used the variable age instead. To check for sensitivity, I set age equal to six. The quantitative results were not altered.
} 
born children have a slight math percentile advantage of 3.37 percentile points over immigrant children. The difference is much larger for reading percentiles--US-born children score about 8.82 percentiles higher than immigrant children. This finding comes as no surprise given that the majority of immigrant children live in non-English speaking households. Lastly, for the years behind variable, we observe that US-born children are held back less in school than immigrant children, and this is consistent regardless of gender. On average, immigrant children are held back 0.27 of a school year more than US-born children. The same pattern is observed after dividing the sample by gender.

Tables $3 \mathrm{~A}$ and $3 \mathrm{~B}$ present some descriptive statistics on various family background variables for children in the San Diego and Miami samples, respectively. We observe from Table 3A and 3B under the column heading "All Children" that the San Diego sample tends to have lower ASAT-READING and ASAT-MATH percentile scores than the Miami sample. The mean ASAT-READING and ASAT-MATH percentiles for the San Diego sample are 37.52 and 48.48, respectively, compared with 43.21 and 56.37 in the Miami sample. This pattern remains after dividing the samples between enclave and non-enclave schools for both San Diego and Miami. Interestingly, non-enclave schools have higher percentiles for both the San Diego and Miami samples.

Looking under the column heading "All Children" for both Tables $3 \mathrm{~A}$ and $3 \mathrm{~B}$, the number of years that immigrant children have lived in the US is about the same in San Diego and Miami, although the Miami sample has very few recent immigrant children under the category "less than five years." The mean age in San Diego is 14.17 and 14.25 in Miami. For the San Diego sample there is an even gender distribution between girls and boys. In the Miami sample 
there are more girls than boys--56 compared to 44 percent. The percentage breakdown of children in grades eight and nine are about the same for both the San Diego and Miami samples.

The CILS survey collected a variety of parental and household information on each child, including parental education, family structure, and home ownership. Parental education is higher in Miami than San Diego. For example, the average education for mothers and fathers in Miami is 12.14 and 12.32 , respectively, versus 11.18 years for mothers and 11.82 years for fathers in San Diego. There are also differences in parental education between enclave and non-enclave schools. For children in enclave schools, average years of schooling for mothers and fathers is much lower than in non-enclave schools. This pattern is seen in both the San Diego and Miami samples. For instance, in the San Diego sample we observed that mean years of schooling for mothers that have a child in an enclave school is 10.35 compared to 11.67 for mothers that have a child in a non-enclave school. In Miami, the averages are 11.71 years in enclave schools compared to 12.82 years in non-enclave schools. A similar pattern is also seen with fathers' educations.

An interesting feature emerges when we look at the household composition by enclave and non-enclave schools. Immigrant parents who are married to a US citizen tend to be concentrated in non-enclave schools. In addition, the fraction of two parent families is higher in non-enclave schools. Home ownership of the parents also varies significantly for children that attend enclave vs. non-enclave schools. That is, parents of non-enclave children are more likely to own their home. These overall patterns between enclave and non-enclave schools for marriage, family structure, and home ownership are seen for both the San Diego and Miami samples. 
We also observe some differences in school-level characteristics in San Diego compared to Miami. While the ethnic student composition in the Miami schools is largely Hispanic, there is no similarly large ethnic group in the San Diego schools. The proportion of children eligible for the federally subsidized lunch program, which is a standard indicator of the average socioeconomic status of a school, is slightly higher for the San Diego schools. About 49 percent of students from the San Diego sample are eligible compared to 46 percent from the Miami sample. This difference is even higher when we further divide the samples into enclave and non-enclave schools. At the enclave Miami schools, 53 percent are eligible for federally subsidized lunch meals, while 64 percent of the San Diego enclave students are eligible. Also, enclave schools are more likely to be in an inner-city location than non-enclave schools. For the San Diego sample, 80 percent of the enclave schools are located in an inner-city. In the Miami sample about 54 percent of the enclave schools are in an inner-city location. Lastly, looking at the pupil/teacher ratio, we observe the San Diego schools have a pupil/teacher ratio of 25.2 and the Miami schools have a pupil/teacher ratio of 25.8. When we divide the sample by enclave schools, we see that the pupil/teacher ratio in the San Diego enclave schools is 24.0, but in the Miami enclave schools the pupil/teacher ratio is 26.6 .

One pattern that emerges from Tables $3 \mathrm{~A}$ and $3 \mathrm{~B}$, is that there are notable differences across enclave and non-enclave schools in both San Diego and Miami. Enclave schools appear to have students that score lower on both reading and math test, and the socioeconomic status of the families are also lower compared to students in non-enclave schools. 


\section{Empirical Specification}

As noted earlier, students were eligible to participate in the CILS if they were US-born and had at least one immigrant parent, or if they were foreign-born and had come to the US before the age of ten (US-born and immigrant children, respectively). This distinction will allow us to analyze the extent to which years in the US affects the academic performance of immigrant children using as a comparison group the US-born children in the sample. I distinguish between three categories of immigrant children: those that have been in the US less than five years, those that have been in the US between five to nine years, and those that have resided in the US for more than ten years. If adaptation occurs, then we should observe the test-score gap, for example, between US-born and immigrant children to narrow as years in the US increases for immigrant children. In addition, there might be different test score outcomes for immigrant children in enclave schools compared to non-enclave schools. The following model specification will allow an analysis of the effects of age at arrival and attendance at an enclave school on the academic performance of immigrant children. Standard OLS estimation is applied to the following model specification:

$$
\begin{gathered}
\operatorname{TEST}_{i}=\alpha_{0}+\mathrm{USYRS}_{i} \delta+\phi_{0} \mathrm{ENCLAVE}_{i}+\mathrm{ENCLAVE}^{*} \mathrm{USYRS}_{i} \pi+ \\
\mathrm{X}_{i} \beta+\mathrm{KIDNAT}_{i} \lambda+\mathrm{SC}_{i} \theta+\mu_{i}
\end{gathered}
$$

where TEST $_{i}$ represents ASAT-READING or ASAT-MATH percentile score of student $i$ in year 1992. USYRS ${ }_{i}$ is a vector of dummy variables indicating number years in the US (i.e., less than five years, between 5 to 9 years, more than 10 years), $\operatorname{ENCLAVE}_{i}$ is a dummy variable indicating an enclave school, and ENCLAVE*USYRS $i$ is a vector of interactions between the enclave school dummy variable and the years in the US variables. The vector $\mathrm{X}_{i}$ is a set of standard controls (i.e., age, gender, grade dummies--eighth and ninth, highest grade completed 
by mother or father, if one parent is US-born, family structure, and home ownership), while $\operatorname{KIDNAT}_{i}$ is a vector for individual nationality controls of the children (Cuban, Mexican, Central American, West Indian, South American, Filipino, Southeast Asian, Asian, and Others). Finally, $\mathrm{SC}_{i}$ is a vector of school characteristics (i.e., pupil/teacher ratio, total school population, percent of students on subsidized lunch meals, and inner-city school dummy). Lastly, $\mu_{i}$ is an i.i.d. error term.

\section{Empirical Results}

The analysis in this section includes only two of the four variables discussed previously in Section 4: the English reading vocabulary and comprehension subtest (ASAT-READING) and the mathematics subtest (ASAT-MATH) from the Abbreviated Stanford Achievement Test.

Tables 4A and 4B report the San Diego and Miami results for two versions of equation (1) for the reading test scores. Model 1 is a parsimonious specification that includes only the $X_{i}$ variables (i.e., age, gender, grade dummies, highest grade completed by mother or father, if one parent is US-born, family structure, and home ownership). Model 2 includes the standard controls plus individual nationality controls for the birth place of the children (i.e., Cuban,

Mexican, Central American, Caribbean, South American, Filipino, Southeast Asian, East and South Asian, and Others). Lastly, Model 3 is the full specification which includes the standard, individual nationality, and school characteristics controls (i.e., pupil/teacher ratio, total school population, percent of students on subsidized lunch meals, and inner-city school dummy). Tables 5A and 5B report the results for the math test scores. 


\section{A ASAT-READING Percentile Score Results}

\section{The Effects of Years in the US on Reading Test Scores}

The coefficients of interest are for the variables indicating years in the US, enclave status, and the interactions between the enclave school dummy and years in the US. US-born children form the reference category. Looking at the results for the first model, for both the San Diego and Miami samples in Tables $4 \mathrm{~A}$ and $4 \mathrm{~B}$, respectively, we observe that the longer an immigrant child resides in the US, the higher is his or her reading test score. In San Diego schools we see that an immigrant child with less than five years in the US scores 17.17 percentiles less than an US-born child, while a child who has been in the US five to nine years scores 4.87 percentiles less, and one who has been in the US for ten or more years scores slightly higher than a US-born child with at least one immigrant parent. In the Miami schools we see the same pattern: an immigrant child with less than five years in the US scores 26.74 percentiles less than an US-born child, while one who has been in the US five to nine years scores 6.02 percentiles lower, and one who has been in the US ten or more years scores only 1.35 percentiles less than an US-born child. The Model 2 and Model 3 specification yields the same general results, which control for the child's nationality and school characteristics for both the San Diego and Miami samples. Overall, the noticeable test score gap between US-born and immigrant children decreases the longer immigrant children reside in the US. These findings suggest that immigrant children that come to the US at an early age and do most of their schooling in the US perform as well as their US-born counter parts on their reading tests.

\section{The Effects of Enclave Schools on Reading Test Scores}

I will now turn to the effects of attending an enclave school on the test scores of immigrant children. I find that, in general, immigrant children that attend enclave schools seem 
to be scoring lower than immigrant children that attend non-enclave schools; however, the differences in test scores between enclave and non-enclave schools are not statistically significant for the San Diego sample, and only marginally significant for the Miami sample.

Looking at Model 1 in Table 4A for the San Diego enclave schools, an immigrant child with less than five years in the US scores $19.09\left(\delta_{1}+\phi_{0}+\pi_{1}=-17.17-2.85+0.93=-19.09\right)$ percentile points less than a US-born child. An immigrant child with five to nine years in the US scores 10.47 percentile points less than an US-born child. Lastly, with more than ten years of residence, an immigrant child scores 3.25 percentiles less than an US-born child. I performed an F-test on all model specifications to test for the significance of the slope and level effects. I find that the slopes of the enclave and non-enclave schools are statistically insignificant, with a corresponding F-statistic of $0.51,0.63$, and 0.32 , respectively. In other words, an immigrant child in an enclave school does not perform any worse than an immigrant child in a non-enclave school. However, I do observe in Model 1 and Model 2 a level effect with a corresponding Fstatistic of 3.05 and 2.14, respectively. That is, children attending an enclave school, regardless if the child is US-born or an immigrant, score 2.85 percentiles (Model 1) and 1.85 percentiles (Model 2) less than children attending a non-enclave school. However, Model 3 shows that after controlling for the schools' characteristics the level effect is no longer salient (with an F-statistic of 0.28$)$.

In Model 1 for the Miami enclave schools we observe, most notably, that an immigrant child with less than five years in the US scores 31.00 percentile points more than a US-born child. However, in the Miami sample there are only 7 immigrant children that have been in the US for less than five years (i.e., 2 observations in enclave schools and 5 observations in the non- 
enclave schools). This result is most likely being driven by two outliers in the data. ${ }^{10}$ If we consider only immigrant children that have resided in the US for more than five years, we then observe that an immigrant child that has lived in the US between five to nine years scores 8.18 percentile points less than a US-born child, and an immigrant child that has resided more than ten years in the US scores 6.82 percentile points less than a US-born child. Model 2 yields the same results after controlling for the children's nationalities.

After testing for slope effects and level effects on all models, I find that there is both a slope and a level effect for the Miami sample; however, these effects are small and only marginally significant. Immigrant children that attend enclave schools are not scoring any lower than immigrant children that attend non-enclave schools. In addition, there is a small enclave effect on test scores regardless if the child is an immigrant or US-born. For example in Model 1, Table 4B, a child attending an enclave school scores 4.23 percentiles less than a child attending a non-enclave school (significant at the 1 percent level with an F-statistics of 7.33). However, after controlling for the children's nationalities and specific schools' characteristics, I find that a child attending an enclave school scores 2.95 percentile points more than a child attending a nonenclave school (significant at the 10 percent level with an F-statistics of 2.02). These findings suggest that for the Miami sample, children attending enclave schools do not perform any worse than the children in non-enclave schools.

\section{B ASAT-MATH Percentiles Score Results}

Briefly, turning to the ASAT-MATH percentile results in Tables 5A and 5B, we see that immigrant children with more than five years of living in the US are scoring about the same or

\footnotetext{
${ }^{10}$ Refer to Appendix for exact sample sizes by US-born children, immigrant children, and school type.
} 
slightly better on the ASAT-MATH test. Focusing on Model 1 (Table 5A) for explanatory purposes, we observe that in San Diego schools an immigrant child with less than five years in the US scores 3.07 percentile points less than a US-born child. With more than five years of US residence the immigrant child has completely caught up. For Miami (Model 1 in Table 5B) we see that an immigrant child with less than five years in the US has a test score disadvantage of 32.15 percentile points. However, with more than five years of US residence the immigrant child only scores 1.30 percentile points less than their US-born counterparts. The math regression results suggest that at least for the first few years of US residence (i.e., less than five) immigrant children have a test score disadvantage; however, after five years they are scoring relatively well on their math tests. With respect to the ASAT-MATH results for the enclave and non-enclave schools, the same conclusions are reached that were observed with the ASATREADING results for the San Diego sample. However, in the Miami sample I do observe a stronger effect on the ASAT-MATH results for immigrant children attending enclave schools. Model 3 shows that after controlling for school characteristics immigrant children attending enclave schools are scoring slightly higher on their math test than immigrant children in nonenclave schools.

\section{C Alternative Model Specification}

In addition to the model specification previously shown, to test for model sensitivity, another model specification is estimated where the distinction between enclave and non-enclave schools is not made, but instead the regression model includes percent of immigrant children for each school. Below is the alternative model specification, which is again estimated by OLS: 


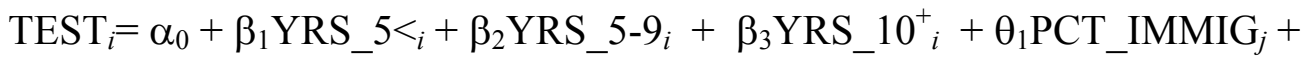

$$
\begin{aligned}
& \theta_{2}\left(\mathrm{PCT} \_\mathrm{IMM} * \mathrm{YRS} \_5<\right)_{i, j}+\theta_{3}\left(\mathrm{PCT} \_\mathrm{IMM} * \mathrm{YRS} \_5-9\right)_{i, j}+\theta_{4}\left(\mathrm{PCT} \text { IMM*YRS_10 } 0^{+}\right)_{i, j}+\mathrm{X}_{i} \delta \\
& +\operatorname{KIDNAT}_{i} \lambda+\mathrm{SC}_{i} \gamma+\varepsilon_{i}
\end{aligned}
$$

where TEST $_{i}$ represents ASAT-READING or ASAT-MATH percentile score of student $i$ in year 1992. YRS_5<, YRS_5-9, and YRS_10 $0^{+}$are dummy variables indicating number of years in the US (i.e., less than five years, between five to nine years, more than ten years). The variable PCT_IMMIG gives the percent of immigrant children for each school j. PCT_IMM*YRS_5<, PCT_IMM*YRS_5-9, and PCT_IMM*YRS_10 ${ }^{+}$are interactions between the variable PCT_IMMIG and the dummy variables indicating number years in the US. $\mathrm{X}_{i}$ is a vector of standard controls (i.e., age, gender, grade dummies--eighth and ninth, highest grade completed by mother or father, if one parent is US-born, family structure, and home ownership). $\mathrm{KIDNAT}_{i}$ is a vector of individual nationality controls for the children (Cuban, Mexican, Central American, West Indian, South American, Filipino, Southeast Asian, Asian, and Others). $\mathrm{SC}_{i}$ is a vector of school characteristics (i.e., percent of White, Black, Hispanic, and Asian/Native American students; total school population; percent of students on subsidized lunch meals; inner-city school dummy; and pupil/teacher ratio). Lastly, $\varepsilon_{i}$ is an i.i.d. error term.

The appendix provides the full set of regression results for the above model specification. The overall conclusions from this alternative specification are qualitatively the same as when the distinction was made between enclave and non-enclave schools.

\section{D Robustness Test: Propensity Score Matching}

In addition to the standard OLS model estimation presented in the previous section, I now address the potential problem of non-random selection in the data with a semi-parametric 
technique most commonly known as propensity score matching (Rosenbaum and Rubin 1983, 1984; Dehejia and Wahba 1995). This alternative procedure attempts to control for potential biases in the sample induced by negative selection into enclave schools. The selectivity into enclave schools may occur for a variety of reasons. For instance, immigrant parents who are less successful in their first few years in the US may have stay in enclaves, leading to a correlation between unobserved parental characteristics and attendance of enclave schools. Unfortunately, I do not have information on previous schools attended by each child in the sample, so I cannot observe children that might have switched between enclave and non-enclave schools. It is possible that I may be observing immigrant children who were self selected into an enclave school setting, and the "true sample" might describe a slightly different story. Hence, an ideal experiment compares the outcomes from two identical immigrant children that are exposed to an enclave and a non-enclave school.

The propensity score matching method is an approximation of such an experiment. The general idea behind this procedure is to match children with similar probabilities of getting the treatment (i.e., attending an enclave school). That is, the best control for any student attending an enclave school is a student who did not, but was equally likely to actually do so on the basis of observables.

The first step of the propensity score method is to run a probit model, where the dependent variable is a binary variable indicating enclave school. The controls used in the probit model were parental education, family structure, and home ownership. After running the probit regression a propensity score, $p$-score, is predicted and this predicted propensity score is used to match each enclave child to a non-enclave child with the closest $p$-score. The final step to this 
procedure is to calculate a simple t-test on the mean difference between the matched ASAT test scores. ${ }^{11}$

The results from the propensity score matching are presented in Tables 6 and 7 for the San Diego and the Miami sample, respectively. In general, the results from the matching technique do not differ qualitatively from the results reported previously that used the standard OLS estimation. This is true for both ASAT-READING and ASAT-MATH test in the San Diego sample. However, for the Miami sample the small enclave effect observed in both test scores is no longer significant with the propensity score estimation.

\section{Conclusions}

This paper analyzes the relationship between age at arrival and immigrant receiving schools on the academic performance of immigrant children. I use the first wave of the Children of Immigrants Longitudinal Study (CILS) 1992-1993 in combination with the Common Core of Data (CCD) 1992-1993. The CILS survey was conducted in two major immigrant receiving cities in the United States--San Diego and Miami, and contains detailed information on academic performance, school characteristics, and parental information of immigrant children.

I compared the academic performance of immigrant children with their US-born counterparts by analyzing their reading and math test scores from the Abbreviated Stanford Achievement Test (ASAT). In addition, I compare the test score outcomes of immigrant children who attend an immigrant receiving school (i.e., enclave school) to those that attend a non-immigrant receiving school (i.e., non-enclave school). These two different school settings

\footnotetext{
${ }^{11}$ The "psmatch" command in STATA is used, which matches the treatment group (i.e., immigrant child in an enclave school) to the control group (i.e., immigrant child in a non-enclave school) with the closest predicted propensity score. In addition, the t-statistics on the mean difference between the matched test scores are also calculated with this command.
} 
could potentially slow-down or speed-up the academic performance of immigrant children. Since immigrant parents tend to settle in predominantly immigrant communities, one might expect the test score outcomes to differ in these two school settings.

I find that the test score gap between US-born and immigrant children narrows with increase in residence tenure of immigrant children. More precisely, with more than ten years in the US, immigrant children perform as well as their US-born counterparts on the reading test; and with more than five years of US residence immigrant children score equally as well as on the math test. I also find that immigrant children in San Diego who attend enclave schools do not perform any worse than immigrant children who attend non-enclave schools. In Miami, on the other hand, there appears to be a small enclave effect on immigrants children's test scores. In addition, I perform a semi-parametric estimation, most commonly known as propensity score matching technique, to counter the non-randomness of the sample induced by selection into enclave schools. This approach attains the same qualitative conclusions as when the standard ordinary least squares is employed for the San Diego sample; however, for the Miami sample the enclave effect is no longer significant. 


\section{References}

Altonji, J., and D. Card (1991). The Effects of Immigration on the Labor Market Outcomes of Less-skilled Natives. In: J. Abowd, and R. Freeman, Immigration, Trade and the Labor Market (pp.201-34). Chicago: University of Chicago Press.

Betts, J. (1998). Educational Crowding Out: Do Immigrants Affect the Educational Attainment of American Minorities. University of California, San Diego mimeo, February.

Borjas, G. (1985). Assimilation, Changes in Cohort Quality, and the Earnings of Immigrants. Journal of Labor Economics 3 (4), 463-489.

Borjas, G. (1987). Self-selection and the Earnings of Immigrants. The American Economic Review 77, 531-553.

Borjas, G. (1992). Ethnic Capital and Intergenerational Mobility. Quarterly Journal of Economics 107 (1), 123-150.

Borjas, G. (1995a). Assimilation, Changes in Cohort Quality Revisited: What Happened to Immigrant Earnings in the 1980s?. Journal of Labor Economics 13, 201-245.

Borjas, G. (1995b). Ethnicity, Neighborhoods, and Human-Capital Externalities. The American Economic Review 85 (3), 365-390.

Borjas, G., R. Freeman, and L. Katz (1992). On the Labor Market Impacts of Immigration and Trade. In: Borjas, G., and R. Freeman, Immigration and the Work Force: Economic Consequences for the United States and Source Areas (pp. 213-44). Chicago: University of Chicago Press.

Card, D. (1990). The Impact of the Mariel Boatlift on the Miami Labor Market. Industrial and Labor Relations Review 43, 245-57.

Card, D. (2001). Immigrant Inflows, Native Outflows, and the Local Labor Market Impacts of Higher Immigration. Journal of Labor Economics 19 (1), 22-64.

Card, D., J. DiNardo, and E. Estes (1998). The More Things Change: Immigrants and the Children of Immigrants in the 1940s, the 1970s, and the 1990s. National Bureau of Economic Research Working Paper, no. 6519.

Card, D., and A. B. Krueger (1992). Does School Quality Matter? Returns to Education and the Characteristics of Public Schools in the United States. Journal of Political Economy 100 (1), 1-40. 
Children of Immigrants Longitudinal Study (CILS) 1992-1993, Wave One. The Center for Migration and Development, Princeton University

Chiswick, B. (1978). The Effect of Americanization on the Earnings of Foreign-Born Men. Journal of Political Economy 86, 897-921.

Cortes, K. E. (2002). Are Refugees Different from Economic Immigrants? Some Empirical Evidence on the Heterogeneity of Immigrant Groups in the United States. University of California, Berkeley mimeo, August. .

Currie, J., and D. Thomas (1999). Early Test Scores, Socioeconomic Status and Future Outcomes. National Bureau of Economic Research Working Paper, no. 6943.

Dehejia, R. H., and S. Wahba (1995). Causal Effects in Non-Experimental Studies: ReEvaluating the Evaluation of Training Programs. Harvard University mimeo, November.

Friedberg, R. M. (1993). The Labor Market Assimilation of Immigrants in the United States: The Role of Age at Arrival. Brown University mimeo, March.

Friedberg, R. M., and J. Hunt (1993). The Impact of Immigrants on Host Country Wages, Employment and Growth. Journal of Economic Perspectives 9 (2), 23-44.

Grossman, J. B. (1982). The Substitutability of Natives and Immigrants in Production. Review of Economics and Statistics 64 (4), 596-603.

Hanushek, E. A (1997). Assessing the Effects of School Resources on Student Performance: An Update. Educational Evaluation and Policy Analysis 19 (2), 141-164.

Hanushek, E. A., S. G. Rivkin, and L. Taylor (1996). Aggregation and the Estimated Effects of School Resources. Review of Economics and Statistics 78 (4), 611-627.

Murnane, R. J., J. B. Willet, and F. Levy (1995). The Growing Importance of Cognitive Skills in Wage Determination. Review of Economics and Statistics 77 (2), 251-266.

Portes, A., and D. MacLeod (1999). Educating the Second Generation: Determinants of Academic Achievement Among Children of Immigrants in the United States. Journal of Ethnic and Migration Studies 25 (3), 373-96.

Rosenbaum, P. R., and D. B. Rubin (1983). "The Central Role of the Propensity Score in Observational Studies for Causal Effects.” Biometrika, vol. 70(1): 41-55.

Rosenbaum, P. R., and D. B. Rubin (1984). Reducing Bias in Observational Studies Using Subclassification on the Propensity Score. Journal of the American Statistical Association 79 (387), 516-524. 
Sexton, E. A., and J. F. Nickel (1992). The Effects of School Location on the Earnings of Black and White Youths. Economics of Education Review 11 (1), 11-18.

Shoeni, R. (1996). The Effect of Immigrants on the Employment and Wages of Native Workers: Evidence from the 1970s and 1980s. RAND Corporation Unpublished Paper.

Urban Institute (2000). Check Points: Data Releases on Economic and Social Issues. The Urban Institute, Office of Public Affairs, Washington DC (September).

U.S. Department of Education, National Center for Education Statistics. COMMON CORE OF DATA: PUBLIC SCHOOL UNIVERSE DATA, 1992-1993 [Computer file]. ICPSR version. Washington, DC: U.S. Department of Education, National Center for Education Statistics [producer], 1993. Ann Arbor, MI: Inter-University Consortium for Political and Social Research [distributor], 1999.

U.S. Government Printing Office. Hearing on Emergency Education Act. Subcommittee on Elementary, Secondary, and Vocational Education of the Committee on Education and Labor, House of Representatives, 98th Congress, Second Session, Washington: U.S. Government Printing Office, 1984. 
TAble 1. SAMPle Sizes of Children by Mother's National ORigin ANd by Percent in Miami and San Diego Public High Schools

\begin{tabular}{|c|c|c|c|c|c|}
\hline \multirow[b]{2}{*}{ Mother's National Origin * } & \multicolumn{5}{|c|}{ US-Born and Immigrant Children $(\mathrm{N}=5055)$} \\
\hline & $\begin{array}{c}\text { Girls } \\
(\mathrm{N}=\mathbf{2 6 5 8})\end{array}$ & $\begin{array}{c}\text { Boys } \\
(\mathrm{N}=2397)\end{array}$ & $\begin{array}{c}\text { Percent } \\
\text { Immigrant }\end{array}$ & $\begin{array}{l}\text { Percent } \\
\text { in Miami }\end{array}$ & $\begin{array}{l}\text { Percent in } \\
\text { San Diego }\end{array}$ \\
\hline Cuban & 555 & 489 & 35.34 & 99.81 & 0.19 \\
\hline Central American ${ }^{a}$ & 259 & 235 & 82.59 & 93.52 & 6.48 \\
\hline Caribbean $^{b}$ & 351 & 204 & 55.86 & 95.50 & 4.50 \\
\hline South American ${ }^{c}$ & 229 & 191 & 54.06 & 92.86 & 7.14 \\
\hline Mexican & 366 & 388 & 44.69 & 3.58 & 96.42 \\
\hline Filipino & 412 & 407 & 52.87 & 1.34 & 98.66 \\
\hline Southeast Asian d & 337 & 336 & 89.45 & 1.49 & 98.51 \\
\hline East and South Asian ${ }^{\text {e }}$ & 86 & 86 & 46.51 & 26.16 & 73.84 \\
\hline Other $^{\mathrm{f}}$ & 63 & 61 & 33.06 & 95.16 & 4.84 \\
\hline \multicolumn{6}{|c|}{$\begin{array}{l}\text { Notes: }{ }^{*} \text { Sample includes both US-born and immigrant children under the heading column Girls and Boys. } \\
\text { ac Central Americans consist of: Nicaraguans, Salvadorians, Guatemalans, Honduras, Costa Ricans, and } \\
\text { Panamanians. }{ }^{\mathrm{b}} \text { Caribbeans consist of: Dominicans, Jamaicans and West Indies. }{ }^{\mathrm{c}} \text { South Americans consist of: } \\
\text { Colombians, Argentineans, Chileans, Ecuadorians, Peruvians, and Venezuelans. }{ }^{\mathrm{d}} \text { Southeast Asians consist of: } \\
\text { Vietnamese, Laotians, Cambodians, and Hmongs. }{ }^{\mathrm{e} E a s t} \text { and South Asians consist of: Chinese, Taiwanese, } \\
\text { Japanese, Koreans, Indians, and Pakistanis. }{ }^{\mathrm{f}} \text { Other consists of the following smaller groups: Middle East, Africa, } \\
\text { Europe, and Canada. } \\
\text { Source: Children of Immigrants Longitudinal Study (CILS) 1992, Wave T1. }\end{array}$} \\
\hline
\end{tabular}


Table 2. Summary Statistics of School Performance by US-BORN AND IMMIGRANT CHILDREN

\begin{tabular}{c|ccc|ccc}
\hline \hline & \multicolumn{5}{|c|}{ US-Born Children } & \multicolumn{3}{c}{ Immigrant Children } \\
\hline $\begin{array}{c}\text { Means Outcome } \\
\text { Variables }\end{array}$ & Girl & Boy & Pooled & Girl & Boy & Pooled \\
\hline Weekly Homework & 2.51 & 2.28 & 2.40 & 2.72 & 2.38 & 2.55 \\
$\quad$ Hours & $(1.29)$ & $(1.34)$ & $(1.32)$ & $(1.38)$ & $(1.35)$ & $(1.37)$ \\
Math Percentile & 55.26 & 53.09 & 54.26 & 52.39 & 49.20 & 50.89 \\
& $(29.30)$ & $(30.10)$ & $(29.68)$ & $(29.47)$ & $(29.40)$ & $(29.48)$ \\
& & & & & & \\
Reading Percentile & 47.07 & 43.75 & 45.53 & 38.54 & 34.66 & 36.71 \\
& $(26.46)$ & $(27.02)$ & $(26.76)$ & $(27.68)$ & $(27.68)$ & $(27.74)$ \\
Years Behind & 0.5812 & 0.7324 & 0.6523 & 0.8890 & 0.9565 & 0.9212 \\
& $(0.6032)$ & $(0.6606)$ & $(0.6352)$ & $(0.6695)$ & $(0.7311)$ & $(0.7003)$ \\
& & & & & & \\
\hline
\end{tabular}

\begin{tabular}{clll}
\hline $\begin{array}{c}\text { Mean Differences } \\
\text { for US-Born and } \\
\text { Immigrant } \\
\text { Children: }\end{array}$ & Pooled Sample & Girl Sample & Boy Sample \\
\hline Weekly Homework & $-0.15^{* * *}$ & $-0.21^{* * *}$ & $-0.10^{*}$ \\
Hours & $(0.04)$ & $(0.05)$ & $(0.06)$ \\
Math Percentile & $3.37^{* * *}$ & $2.87^{* *}$ & $3.89^{* * *}$ \\
& $(0.90)$ & $(1.23)$ & $(1.33)$ \\
Reading Percentile & $8.82^{* * *}$ & $8.53^{* * *}$ & $9.09^{* * *}$ \\
& $(0.83)$ & $(1.12)$ & $(1.21)$ \\
Years Behind & $-0.27^{* * *}$ & $-0.31^{* * *}$ & $-0.22^{* * *}$ \\
& $(0.02)$ & $(0.03)$ & $(0.03)$ \\
\hline
\end{tabular}

Notes: ***,**,* Mean differences are statistically significant at the 1, 5, and 10 levels. Standard errors are in parentheses. The variable years behind $=($ age-grade-5 $)$.

Source: Children of Immigrants Longitudinal Study (CILS) 1992, Wave T1. 
Table 3A. Descriptive Statistics -San Diego SAMPle

\begin{tabular}{|c|c|c|c|c|c|c|}
\hline \multirow{2}{*}{ Dependent Variables } & \multicolumn{2}{|c|}{ All Schools } & \multicolumn{2}{|c|}{ Enclave Schools } & \multicolumn{2}{|c|}{ Non-Enclave Schools } \\
\hline & & & & & & \\
\hline$\overline{\text { ASAT Reading Percentiles }}$ & 37.52 & $(29.95)$ & 29.69 & (29.19) & 42.20 & $(29.43)$ \\
\hline ASAT Math Percentiles & 48.48 & $(30.76)$ & 43.70 & $(31.34)$ & 51.33 & $(30.07)$ \\
\hline \multicolumn{7}{|l|}{ Years in the US } \\
\hline Less than 5 & 0.057 & $(0.232)$ & 0.082 & $(0.274)$ & 0.043 & $(0.202)$ \\
\hline Between 5-9 & 0.206 & $(0.404)$ & 0.276 & $(0.447)$ & 0.164 & $(0.370)$ \\
\hline 10 or more & 0.302 & $(0.459)$ & 0.333 & $(0.472)$ & 0.283 & $(0.451)$ \\
\hline US-Born & 0.435 & $(0.496)$ & 0.309 & $(0.462)$ & 0.511 & $(0.500)$ \\
\hline \multicolumn{7}{|l|}{ Basic Controls } \\
\hline$\overline{\text { Age }}$ & 14.17 & $(0.845)$ & 14.09 & $(0.878)$ & 14.22 & $(0.822)$ \\
\hline Girl & 0.501 & $(0.500)$ & 0.490 & $(0.500)$ & 0.508 & $(0.500)$ \\
\hline \multicolumn{7}{|l|}{ Grade Dummies } \\
\hline Eight Grade & 0.542 & $(0.498)$ & 0.709 & $(0.454)$ & 0.443 & $(0.497)$ \\
\hline Ninth Grade & 0.457 & $(0.498)$ & 0.291 & $(0.454)$ & 0.557 & $(0.497)$ \\
\hline Mother's Education & 11.18 & (3.799) & 10.35 & $(3.540)$ & 11.67 & (3.864) \\
\hline Father's Education & 11.82 & $(3.426)$ & 11.17 & $(3.426)$ & 12.21 & $(3.368)$ \\
\hline \multicolumn{7}{|l|}{ Family Background Controls } \\
\hline One Parent US-Born & 0.161 & $(0.368)$ & 0.127 & $(0.333)$ & 0.180 & $(0.386)$ \\
\hline \multicolumn{7}{|l|}{ Family Structure } \\
\hline 2 Biological Parents & 0.726 & $(0.446)$ & 0.681 & $(0.466)$ & 0.752 & $(0.432)$ \\
\hline 1 Biological and Step Parent & 0.095 & $(0.293)$ & 0.086 & $(0.280)$ & 0.100 & $(0.300)$ \\
\hline 1 Parent: Mom or Dad Alone & 0.157 & $(0.364)$ & 0.206 & $(0.405)$ & 0.128 & $(0.335)$ \\
\hline Other Guardian & 0.022 & $(0.147)$ & 0.026 & $(0.160)$ & 0.020 & $(0.139)$ \\
\hline Parents Own Their Home & 0.498 & $(0.500)$ & 0.308 & $(0.462)$ & 0.612 & $(0.487)$ \\
\hline \multicolumn{7}{|l|}{ Nationality Controls } \\
\hline Cuban & 0.001 & $(0.031)$ & -- & -- & 0.002 & $(0.040)$ \\
\hline Central American & 0.011 & $(0.104)$ & 0.009 & $(0.096)$ & 0.012 & $(0.108)$ \\
\hline Caribbean & 0.009 & $(0.096)$ & 0.011 & $(0.102)$ & 0.009 & $(0.093)$ \\
\hline South American & 0.010 & $(0.101)$ & 0.008 & $(0.089)$ & 0.012 & $(0.108)$ \\
\hline Mexican & 0.288 & $(0.453)$ & 0.287 & $(0.452)$ & 0.289 & $(0.454)$ \\
\hline Filipino & 0.350 & $(0.477)$ & 0.148 & $(0.355)$ & 0.471 & $(0.499)$ \\
\hline Southeast Asian & 0.277 & $(0.447)$ & 0.491 & $(0.500)$ & 0.149 & $(0.356)$ \\
\hline East and South Asian & 0.050 & $(0.219)$ & 0.044 & $(0.204)$ & 0.054 & $(0.227)$ \\
\hline Other & 0.002 & $(0.050)$ & 0.003 & $(0.051)$ & 0.002 & $(0.049)$ \\
\hline \multicolumn{7}{|l|}{ School Controls } \\
\hline$\overline{\text { Percent White }}$ & 31.67 & $(15.58)$ & 28.56 & $(13.80)$ & 33.52 & $(16.26)$ \\
\hline Percent Black & 14.33 & (7.968) & 16.36 & $(10.76)$ & 13.11 & $(5.311)$ \\
\hline Percent Hispanic & 23.69 & (16.86) & 24.72 & $(11.10)$ & 23.08 & $(19.49)$ \\
\hline Percent Asian/Native American & 30.19 & $(14.08)$ & 30.04 & $(10.20)$ & 30.29 & $(15.96)$ \\
\hline Percent Subsidized Lunch & 49.40 & $(22.28)$ & 64.20 & (22.59) & 40.58 & $(16.73)$ \\
\hline School Population & 1606 & $(548.4)$ & 1326 & $(474.5)$ & 1772 & $(521.1)$ \\
\hline Inner-city Location & 0.398 & $(0.490)$ & 0.803 & $(0.340)$ & 0.157 & $(0.364)$ \\
\hline Pupil/Teacher Ratio & 25.20 & $(2.142)$ & 24.05 & $(1.488)$ & 25.89 & $(2.180)$ \\
\hline Sample Size & \multicolumn{2}{|c|}{2026} & \multicolumn{2}{|c|}{757} & \multicolumn{2}{|c|}{1269} \\
\hline
\end{tabular}


TABle 3B. Descriptive Statistics -Miami SAMPle

\begin{tabular}{|c|c|c|c|c|c|c|}
\hline \multirow{2}{*}{ Dependent Variables } & \multicolumn{2}{|c|}{ All Schools } & \multicolumn{2}{|c|}{ Enclave Schools } & \multicolumn{2}{|c|}{ Non-Enclave Schools } \\
\hline & & & & & & \\
\hline$\overline{\text { ASAT Reading Percentiles }}$ & 43.21 & $(24.56)$ & 39.92 & $(23.68)$ & 48.33 & $(25.03)$ \\
\hline ASAT Math Percentiles & 56.37 & $(27.94)$ & 52.18 & $(27.17)$ & 62.89 & $(27.88)$ \\
\hline \multicolumn{7}{|l|}{ Years in the US } \\
\hline$\overline{\text { Less than } 5}$ & 0.003 & $(0.056)$ & 0.001 & $(0.038)$ & 0.006 & $(0.075)$ \\
\hline Between 5-9 & 0.239 & $(0.426)$ & 0.282 & $(0.450)$ & 0.172 & $(0.377)$ \\
\hline 10 or more & 0.269 & $(0.444)$ & 0.294 & $(0.456)$ & 0.231 & $(0.422)$ \\
\hline US-Born & 0.489 & $(0.499)$ & 0.423 & $(0.494)$ & 0.590 & $(0.492)$ \\
\hline \multicolumn{7}{|l|}{ Basic Controls } \\
\hline$\overline{\text { Age }}$ & 14.25 & $(0.853)$ & 14.42 & $(0.848)$ & 13.99 & $(0.790)$ \\
\hline Girl & 0.561 & $(0.496)$ & 0.568 & $(0.496)$ & 0.550 & $(0.497)$ \\
\hline \multicolumn{7}{|l|}{ Grade Dummies } \\
\hline Eight Grade & 0.561 & $(0.496)$ & 0.422 & $(0.494)$ & 0.776 & $(0.417)$ \\
\hline Ninth Grade & 0.439 & $(0.496)$ & 0.578 & $(0.494)$ & 0.224 & $(0.417)$ \\
\hline Mother's Education & 12.14 & $(3.202)$ & 11.71 & $(3.321)$ & 12.82 & $(2.882)$ \\
\hline Father's Education & 12.32 & $(3.231)$ & 11.78 & $(3.292)$ & 13.16 & $(2.943)$ \\
\hline \multicolumn{7}{|l|}{ Family Background Controls } \\
\hline One Parent US-Born & 0.127 & $(0.333)$ & 0.083 & $(0.276)$ & 0.196 & $(0.397)$ \\
\hline \multicolumn{7}{|l|}{ Family Structure } \\
\hline 2 Biological Parents & 0.583 & $(0.493)$ & 0.542 & $(0.498)$ & 0.646 & $(0.478)$ \\
\hline 1 Biological and Step Parent & 0.151 & $(0.358)$ & 0.160 & $(0.364)$ & 0.137 & $(0.344)$ \\
\hline 1 Parent: Mom or Dad Alone & 0.239 & $(0.427)$ & 0.263 & $(0.440)$ & 0.203 & $(0.402)$ \\
\hline Other Guardian & 0.027 & $(0.162)$ & 0.035 & $(0.184)$ & 0.014 & $(0.116)$ \\
\hline Parents Own Their Home & 0.594 & $(0.491)$ & 0.508 & $(0.500)$ & 0.729 & $(0.445)$ \\
\hline \multicolumn{7}{|l|}{ Nationality Controls } \\
\hline Cuban & 0.409 & $(0.492)$ & 0.416 & $(0.493)$ & 0.398 & $(0.490)$ \\
\hline Central American & 0.188 & $(0.390)$ & 0.234 & $(0.224)$ & 0.113 & $(0.317)$ \\
\hline Caribbean & 0.179 & $(0.383)$ & 0.174 & $(0.380)$ & 0.185 & $(0.389)$ \\
\hline South American & 0.150 & $(0.358)$ & 0.137 & $(0.344)$ & 0.172 & $(0.377)$ \\
\hline Mexican & 0.011 & $(0.103)$ & 0.010 & $(0.101)$ & 0.011 & $(0.106)$ \\
\hline Filipino & 0.004 & $(0.067)$ & 0.004 & $(0.061)$ & 0.006 & $(0.075)$ \\
\hline Southeast Asian & 0.004 & $(0.060)$ & -- & -- & 0.009 & $(0.095)$ \\
\hline East and South Asian & 0.017 & $(0.129)$ & 0.007 & $(0.085)$ & 0.032 & $(0.176)$ \\
\hline Other & 0.039 & $(0.195)$ & 0.018 & $(0.132)$ & 0.073 & $(0.261)$ \\
\hline \multicolumn{7}{|l|}{ School Controls } \\
\hline Percent White & 17.47 & $(19.32)$ & 5.943 & $(5.028)$ & 35.37 & (19.66) \\
\hline Percent Black & 16.13 & $(21.80)$ & 17.20 & $(23.09)$ & 14.47 & $(19.52)$ \\
\hline Percent Hispanic & 64.74 & $(30.17)$ & 75.70 & $(25.53)$ & 47.69 & $(28.90)$ \\
\hline Percent Asian/Native American & 1.549 & $(1.381)$ & 0.953 & $(0.375)$ & 2.478 & (1.799) \\
\hline Percent Subsidized Lunch & 45.87 & (23.94) & 52.76 & (24.49) & 35.17 & $(18.56)$ \\
\hline School Population & 2061 & $(871.9)$ & 2374 & $(962.6)$ & 1570 & $(322.6)$ \\
\hline Inner-city Location & 0.347 & $(0.476)$ & 0.535 & $(0.500)$ & 0.054 & $(0.226)$ \\
\hline Pupil/Teacher Ratio & 25.77 & $(3.012)$ & 26.57 & (2.954) & 24.52 & $(2.659)$ \\
\hline Sample Size & \multicolumn{2}{|c|}{2233} & \multicolumn{2}{|c|}{1359} & \multicolumn{2}{|c|}{874} \\
\hline
\end{tabular}

Notes: These descriptive statistics are based on the pooled sample of both US-born and immigrant children. Means and standard deviations are in parentheses.

Source: Children of Immigrants Longitudinal Study (CILS) 1992, Wave T1, and Common Core of Data (CCD) $1992-1993$. 


\section{TABLE 4A. OLS RESULTS--DEPENDENT VARIABLE: ASAT Standardized Reading Percentile}

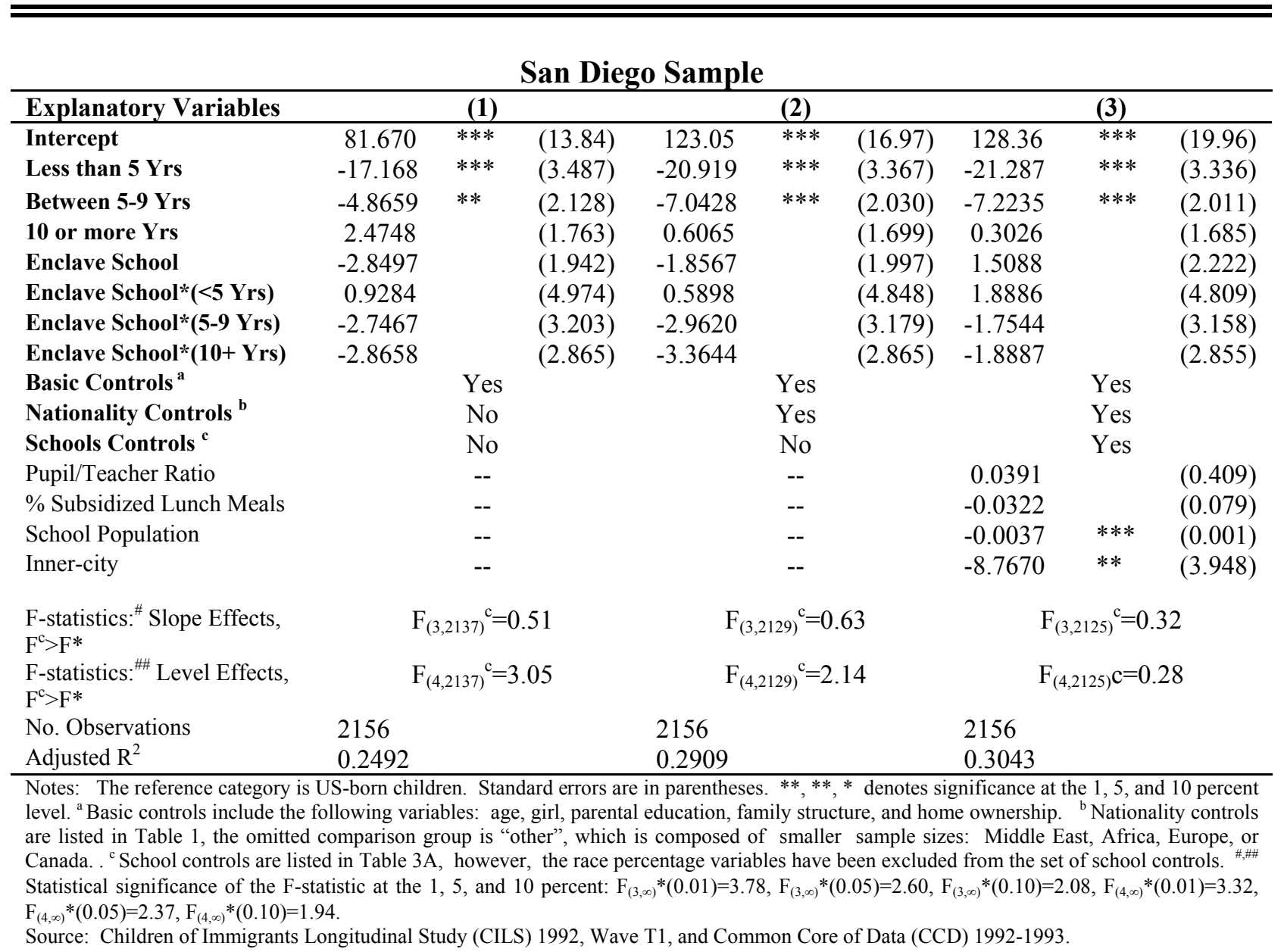




\section{TABle 4B. OLS Results--DEPENDENT VARIABLE: ASAT Standardized Reading Percentile}

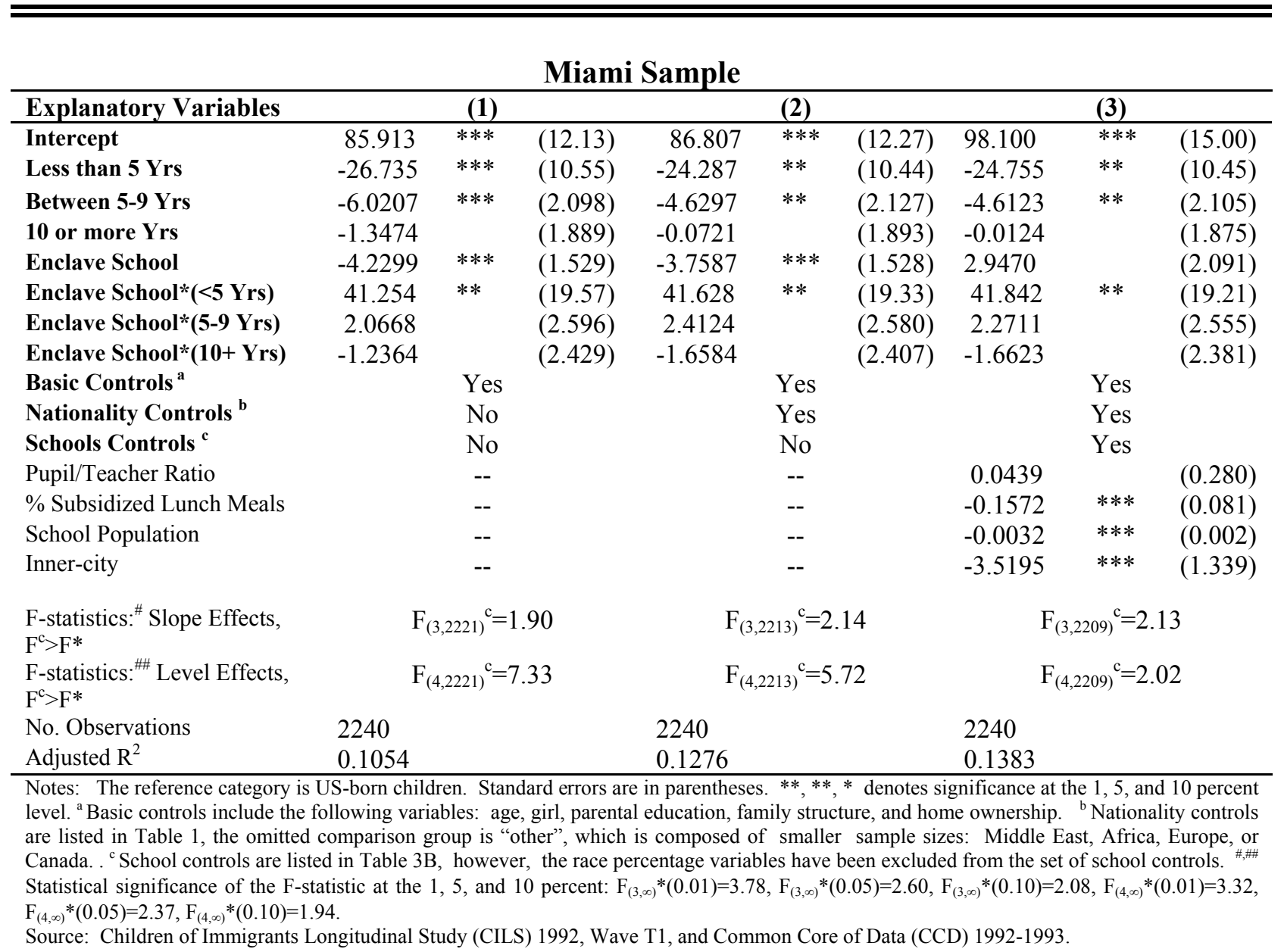


TABLE 5A. OLS Results--DePendent VARIABLE: aSAT Standardized Math Percentile

San Diego Sample

\begin{tabular}{|c|c|c|c|c|c|c|c|c|c|}
\hline Explanatory Variables & \multicolumn{3}{|c|}{ (1) } & \multicolumn{3}{|c|}{ (2) } & \multicolumn{3}{|c|}{ (3) } \\
\hline Intercept & 126.91 & $* * *$ & $(15.32)$ & 140.36 & $* * *$ & $(19.07)$ & 148.94 & *** & $(22.58)$ \\
\hline Less than 5 Yrs & -3.0675 & & $(3.693)$ & -7.3038 & $* *$ & $(3.569)$ & -7.6244 & ** & $(3.570)$ \\
\hline Between 5-9 Yrs & 2.3271 & & $(2.318)$ & -1.1857 & & $(2.240)$ & -1.3745 & & $(2.232)$ \\
\hline 10 or more Yrs & 3.4684 & * & $(1.907)$ & -0.8049 & & $(1.871)$ & -1.0161 & & $(1.866)$ \\
\hline Enclave School & -2.3956 & & $(2.233)$ & -1.1711 & & $(2.161)$ & 3.1643 & & $(2.408)$ \\
\hline Enclave School ${ }^{*}(<5$ Yrs) & 7.5393 & & $(5.290)$ & 3.9059 & & $(5.113)$ & 5.0202 & & $(5.105)$ \\
\hline Enclave School*(5-9 Yrs) & 1.9635 & & $(3.532)$ & -3.0771 & & $(3.449)$ & -2.0753 & & $(3.443)$ \\
\hline Enclave School*(10+ Yrs) & 1.4704 & & (3.193) & -3.7591 & & (3.112) & -2.5861 & & (3.112) \\
\hline Basic Controls $^{a}$ & \multicolumn{3}{|c|}{ Yes } & \multicolumn{3}{|c|}{ Yes } & \multicolumn{3}{|c|}{ Yes } \\
\hline Nationality Controls $^{\text {b }}$ & \multicolumn{3}{|c|}{ No } & \multicolumn{3}{|c|}{ Yes } & \multicolumn{3}{|c|}{ Yes } \\
\hline Schools Controls ${ }^{c}$ & \multirow{2}{*}{\multicolumn{3}{|c|}{ No }} & \multicolumn{3}{|c|}{ No } & \multicolumn{3}{|c|}{ Yes } \\
\hline Pupil/Teacher Ratio & \multirow{2}{*}{\multicolumn{3}{|c|}{--}} & \multicolumn{3}{|c|}{--} & -0.5089 & & $(0.447)$ \\
\hline$\%$ Subsidized Lunch Meals & & & & \multirow{2}{*}{\multicolumn{3}{|c|}{--}} & 0.0005 & & $(0.085)$ \\
\hline School Population & \multicolumn{3}{|c|}{--} & \multirow{2}{*}{\multicolumn{3}{|c|}{$\begin{array}{l}-- \\
--\end{array}$}} & 0.0010 & & $(0.001)$ \\
\hline Inner-city & \multicolumn{3}{|c|}{$\begin{array}{l}-- \\
--\end{array}$} & & & & -10.303 & $* *$ & $(4.255)$ \\
\hline $\begin{array}{l}\text { F-statistics: }{ }^{\#} \text { Slope Effects, } \\
\mathrm{F}^{\mathrm{c}}>\mathrm{F}^{*}\end{array}$ & \multicolumn{3}{|c|}{$\mathrm{F}_{(3,2035)}{ }^{\mathrm{c}}=0.69$} & \multicolumn{3}{|c|}{$\mathrm{F}_{(3,2027)}{ }^{\mathrm{c}}=1.06$} & \multicolumn{3}{|c|}{$\mathrm{F}_{(3,2023)}{ }^{\mathrm{c}}=0.85$} \\
\hline $\begin{array}{l}\text { F-statistics: }{ }^{\prime \prime} \text { Level Effects, } \\
\mathrm{F}^{\mathrm{c}}>\mathrm{F}^{*}\end{array}$ & \multicolumn{3}{|c|}{$\mathrm{F}_{(4,2035)}{ }^{\mathrm{c}}=0.61$} & \multicolumn{3}{|c|}{$\mathrm{F}_{(4,2027)}{ }^{\mathrm{c}}=1.65$} & \multicolumn{3}{|c|}{$\mathrm{F}_{(4,2023)}{ }^{\mathrm{c}}=1.05$} \\
\hline No. Observations & 2054 & & & 2156 & & & 2054 & & \\
\hline Adjusted $\mathrm{R}^{2}$ & 0.1527 & & & 0.2229 & & & 0.2300 & & \\
\hline
\end{tabular}

Notes: The reference category is US-born children. Standard errors are in parentheses. ${ }^{* *},{ }^{* *},{ }^{*}$ denotes significance at the 1,5 , and 10 percent level. ${ }^{a}$ Basic controls include the following variables: age, girl, parental education, family structure, and home ownership. ${ }^{\mathrm{b}}$ Nationality controls are listed in Table 1, the omitted comparison group is "other", which is composed of smaller sample sizes: Middle East, Africa, Europe, or Canada. . ${ }^{\mathrm{C}}$ School controls are listed in Table 3A, however, the race percentage variables have been excluded from the set of school controls. \#,\#\# Statistical significance of the F-statistic at the 1,5 , and 10 percent: $\mathrm{F}_{(3, \infty)} *(0.01)=3.78, \mathrm{~F}_{(3, \infty)} *(0.05)=2.60, \mathrm{~F}_{(3, \infty)} *(0.10)=2.08, \mathrm{~F}_{(4, \infty)} *(0.01)=3.32$, $\mathrm{F}_{(4, \infty)} *(0.05)=2.37, \mathrm{~F}_{(4, \infty)} *(0.10)=1.94$.

Source: Children of Immigrants Longitudinal Study (CILS) 1992, Wave T1, and Common Core of Data (CCD) 1992-1993. 
TABLE 5B. OLS RESULTS--DEPENDENT VARIABLE: ASAT Standardized Math Percentile

\begin{tabular}{|c|c|c|c|c|c|c|c|c|c|}
\hline \multicolumn{10}{|c|}{ Miami Sample } \\
\hline \multirow{2}{*}{$\begin{array}{l}\text { Explanatory Variables } \\
\text { Intercept }\end{array}$} & \multicolumn{3}{|c|}{ (1) } & \multicolumn{3}{|c|}{ (2) } & \multicolumn{3}{|c|}{ (3) } \\
\hline & 134.40 & $* * *$ & $(13.88)$ & 135.72 & $* * *$ & (13.94) & 130.99 & $* * *$ & $(15.02)$ \\
\hline Less than 5 Yrs & -32.154 & $* * *$ & (12.03) & -30.262 & $* * *$ & $(11.87)$ & -30.001 & $* * *$ & $(11.70)$ \\
\hline Between 5-9 Yrs & -1.3016 & & $(2.391)$ & -1.5076 & & $(2.417)$ & -1.3792 & & $(2.382)$ \\
\hline 10 or more Yrs & -0.9057 & & (2.147) & -0.7399 & & $(2.146)$ & -0.7848 & & $(2.115)$ \\
\hline Enclave School & -8.2076 & $* * *$ & (1.739) & -7.9629 & $* * *$ & (1.734) & -1.4696 & & (2.309) \\
\hline Enclave School*(<5 Yrs) & 49.835 & $* *$ & $(22.31)$ & 50.806 & $* *$ & (21.99) & 58.806 & $* * *$ & $(21.70)$ \\
\hline Enclave School*(5-9 Yrs) & 5.6581 & $*$ & $(2.956)$ & 5.8924 & $* *$ & $(2.932)$ & 6.0834 & $* *$ & $(2.889)$ \\
\hline Enclave School*(10+ Yrs) & 1.3157 & & $(2.763)$ & 1.3931 & & $(2.732)$ & 1.9011 & & $(2.691)$ \\
\hline Basic Controls $^{\mathrm{a}}$ & & Yes & & & Yes & & & Yes & \\
\hline Nationality Controls $^{\text {b }}$ & & No & & & Yes & & & Yes & \\
\hline Schools Controls ${ }^{c}$ & & No & & & No & & & Yes & \\
\hline Pupil/Teacher Ratio & & -- & & & -- & & 0.8837 & $* * *$ & $(0.282)$ \\
\hline \% Subsidized Lunch Meals & & -- & & & -- & & -0.1010 & $* *$ & $(0.045)$ \\
\hline School Population & & -- & & & -- & & -0.0040 & $* * *$ & $(0.001)$ \\
\hline Inner-city & & -- & & & -- & & -10.433 & $* * *$ & $(1.412)$ \\
\hline $\begin{array}{l}\text { F-statistics:" Slope Effects, } \\
\mathrm{F}^{\mathrm{c}}>\mathrm{F}^{*}\end{array}$ & & $226)^{c}=$ & & & $118)^{c}=3$ & & & $214)^{c}=?$ & \\
\hline $\begin{array}{l}\text { F-statistics: }{ }^{\# \#} \text { Level Effects, } \\
\mathrm{F}^{\mathrm{c}}>\mathrm{F}^{*}\end{array}$ & & ${ }_{226)}^{c}=$ & & & $18)^{c}=1$ & & & 214) & \\
\hline No. Observations & 2245 & & & 2245 & & & 2245 & & \\
\hline Adjusted $\mathrm{R}^{2}$ & 0.1013 & & & 0.1271 & & & 0.1539 & & \\
\hline
\end{tabular}

Notes: The reference category is US-born children. Standard errors are in parentheses. **, **, * denotes significance at the 1,5 , and 10 percent level. ${ }^{a}$ Basic controls include the following variables: age, girl, parental education, family structure, and home ownership. ${ }^{\mathrm{b}}$ Nationality controls are listed in Table 1, the omitted comparison group is "other", which is composed of smaller sample sizes: Middle East, Africa, Europe, or Canada. . ' School controls are listed in Table 3B, however, the race percentage variables have been excluded from the set of school controls. \#\#\# Statistical significance of the F-statistic at the 1,5 , and 10 percent: $\mathrm{F}_{(3, \infty)} *(0.01)=3.78, \mathrm{~F}_{(3, \infty)} *(0.05)=2.60, \mathrm{~F}_{(3, \infty)} *(0.10)=2.08, \mathrm{~F}_{(4, \infty)} *(0.01)=3.32$, $\mathrm{F}_{(4, \infty)} *(0.05)=2.37, \mathrm{~F}_{(4, \infty)} *(0.10)=1.94$.

Source: Children of Immigrants Longitudinal Study (CILS) 1992, Wave T1, and Common Core of Data (CCD) 1992-1993. 
Table 6. Propensity Score Matching Results

\begin{tabular}{|c|c|c|c|c|c|}
\hline \multicolumn{6}{|c|}{ San Diego Sample } \\
\hline ASAT-READING Percentiles & $\begin{array}{c}\text { Mean of } \\
\text { Treated, } \\
\text { Enclave } \\
\text { School } \\
\text { Attendees } \\
\end{array}$ & $\begin{array}{c}\text { Mean of } \\
\text { Control, } \\
\text { Non-enclave } \\
\text { School } \\
\text { Attendees } \\
\end{array}$ & Mean & Difference & $\begin{array}{c}\text { t-statistic } \\
\text { for } \mathbf{H}_{0} \text { : } \\
\text { Mean Difference=0 }\end{array}$ \\
\hline Less than 5 Years in the US & 14.547 & 19.016 & -4.469 & (9.1513) & -0.4884 \\
\hline Between 5-9 Years in the US & 22.329 & 28.860 & -6.531 & $(4.2186)$ & -1.5882 \\
\hline 10 or more Years in the US & 31.152 & 37.657 & -6.505 & $(3.4431)$ & -1.8892 \\
\hline US-Born & 38.056 & 38.191 & -0.132 & $(3.0756)$ & -0.0431 \\
\hline ASAT-MATH Percentiles & $\begin{array}{c}\text { Mean of } \\
\text { Treated, } \\
\text { Enclave } \\
\text { School } \\
\text { Attendees } \\
\end{array}$ & $\begin{array}{c}\text { Mean of } \\
\text { Control, } \\
\text { Non-enclave } \\
\text { School } \\
\text { Attendees } \\
\end{array}$ & Mean & Difference & $\begin{array}{c}\text { t-statistic } \\
\text { for } \mathbf{H}_{0}: \\
\text { Mean Difference=0 }\end{array}$ \\
\hline Less than 5 Years in the US & 40.463 & 36.582 & 3.881 & $(10.676)$ & 0.3635 \\
\hline Between 5-9 Years in the US & 42.474 & 42.621 & -0.147 & $(4.5307)$ & -0.0326 \\
\hline 10 or more Years in the US & 44.733 & 47.686 & -2.953 & $(3.7417)$ & -0.7893 \\
\hline US-Born & 43.996 & 46.374 & -2.278 & (3.2949) & -0.6914 \\
\hline
\end{tabular}

Notes: Standard errors are in parentheses.

Source: Children of Immigrants Longitudinal Study (CILS) 1992, Wave T1, and Common Core of Data (CCD) $1992-1993$. 
Table 7. Propensity Score Matching Results

\begin{tabular}{|c|c|c|c|c|}
\hline \multicolumn{5}{|c|}{ Miami Sample } \\
\hline ASAT-READING Percentiles & $\begin{array}{c}\text { Mean of } \\
\text { Treated, } \\
\text { Enclave } \\
\text { School } \\
\text { Attendees } \\
\end{array}$ & $\begin{array}{c}\text { Mean of } \\
\text { Control, } \\
\text { Non-enclave } \\
\text { School } \\
\text { Attendees } \\
\end{array}$ & Mean Difference & $\begin{array}{c}\text { t-statistic } \\
\text { for } \mathrm{H}_{0}: \\
\text { Mean Difference }=0\end{array}$ \\
\hline Between 5-9 Years in the US & 36.965 & 42.244 & $(3.3252)$ & -1.5875 \\
\hline 10 or more Years in the US & 38.722 & 44.491 & $(3.3984)$ & -1.6975 \\
\hline US-Born & 42.676 & 44.386 & $(2.3496)$ & -0.7279 \\
\hline ASAT-MATH Percentiles & $\begin{array}{l}\text { Mean of } \\
\text { Treated, } \\
\text { Enclave } \\
\text { School } \\
\text { Attendees } \\
\end{array}$ & $\begin{array}{c}\text { Mean of } \\
\text { Control, } \\
\text { Non-enclave } \\
\text { School } \\
\text { Attendees } \\
\end{array}$ & Mean Difference & $\begin{array}{c}\text { t-statistic } \\
\text { for } \mathrm{H}_{0}: \\
\text { Mean Difference }=0\end{array}$ \\
\hline Between 5-9 Years in the US & 53.945 & 56.605 & $(3.9131)$ & -0.6798 \\
\hline 10 or more Years in the US & 50.648 & 54.638 & $(3.8376)$ & -1.0397 \\
\hline US-Born & 51.898 & 56.751 & $(2.6562)$ & -1.8273 \\
\hline
\end{tabular}




\section{APPENDIX:}

TABle A1. OLS Results For the DePendent VARIABLE: aSAT Standardized Reading Percentile

\begin{tabular}{|c|c|c|c|c|c|c|c|c|c|}
\hline \multicolumn{10}{|c|}{ 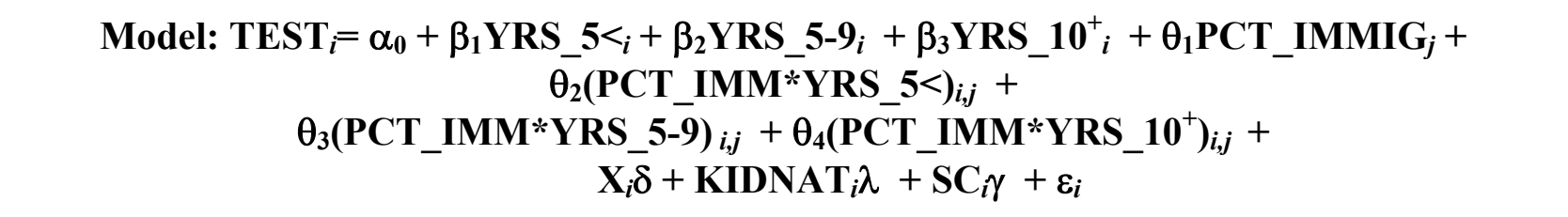 } \\
\hline \multicolumn{10}{|c|}{ San Diego Sample } \\
\hline Explanatory Variables & \multicolumn{3}{|c|}{ (1) } & \multicolumn{3}{|c|}{$(2)$} & \multicolumn{3}{|c|}{ (3) } \\
\hline Intercept & 83.290 & $* * *$ & $(14.12)$ & 122.42 & $* * *$ & $(17.25)$ & 126.07 & $* * *$ & $(20.25)$ \\
\hline Less than 5 Yrs & -15.930 & $*$ & $(8.342)$ & -17.543 & $* *$ & $(8.138)$ & -18.857 & $* *$ & $(8.072)$ \\
\hline Between 5-9 Yrs & -0.7554 & & $(5.123)$ & -1.6817 & & $(5.016)$ & -2.8688 & & $(4.977)$ \\
\hline 10 or more Yrs & 9.7948 & ** & $(4.469)$ & 9.2960 & ** & $(4.360)$ & 7.8267 & $*$ & $(4.330)$ \\
\hline Pct. Recent Immig. Kids & -0.1240 & & $(0.097)$ & -0.0309 & & $(0.096)$ & 0.0852 & & $(0.124)$ \\
\hline$(\%$ Recent Immig)*(<5 Yrs) & -0.0317 & & $(0.233)$ & -0.1027 & & $(0.023)$ & -0.0562 & & $(0.227)$ \\
\hline (\%Recent Immig)*(5-9 Yrs) & -0.1644 & & $(0.148)$ & -0.2102 & & $(0.147)$ & -0.1648 & & $(0.146)$ \\
\hline $\begin{array}{l}\text { (\%Recent Immig)*(10+ } \\
\text { Yrs) }\end{array}$ & -0.2641 & $* *$ & $(0.136)$ & -0.3182 & $* *$ & $(0.135)$ & -0.2661 & $*$ & $(0.134)$ \\
\hline Basic Controls ${ }^{a}$ & & Yes & & & Yes & & & Yes & \\
\hline Nationality Controls ${ }^{b}$ & & No & & & Yes & & & Yes & \\
\hline Schools Controls $^{c}$ & & No & & & No & & & Yes & \\
\hline Pupil/Teacher Ratio & & -- & & & -- & & 0.0682 & & $(0.417)$ \\
\hline$\%$ Subsidized Lunch Meals & & -- & & & -- & & -0.0554 & & $(0.087)$ \\
\hline School Population & & -- & & & -- & & -0.0038 & $* * *$ & $(0.001)$ \\
\hline Inner-city & & -- & & & -- & & -6.6600 & & $(4.854)$ \\
\hline $\begin{array}{l}\text { F-statistics: }{ }^{\#} \text { Slope Effects, } \\
\mathrm{F}^{\mathrm{C}}>\mathrm{F}^{*}\end{array}$ & & $, 2137)^{c}=$ & & & 129) ${ }^{c}=1$ & & & $2125)^{c}=1$ & \\
\hline $\begin{array}{l}\text { F-statistics: }{ }^{\#} \text { Level Effects, } \\
\mathrm{F}^{\mathrm{c}}>\mathrm{F}^{*}\end{array}$ & & $1,2137)^{c=}$ & & & $129)^{c}=3$ & & & $\left.{ }_{125}\right)^{c}=1$ & \\
\hline No. Observations & 2156 & & & 2156 & & & 2156 & & \\
\hline Adjusted $\mathrm{R}^{2}$ & 0.2525 & & & 0.2930 & & & 0.3053 & & \\
\hline \multicolumn{10}{|c|}{ 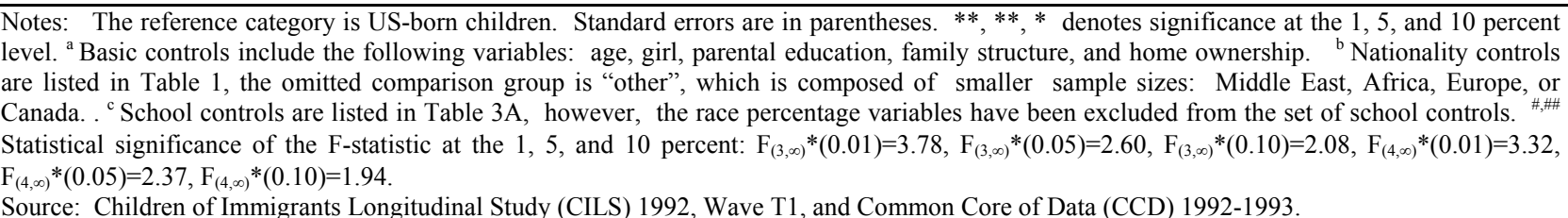 } \\
\hline
\end{tabular}


TABle A2. OLS Results for THe DePendent Variable: aSat Standardized Reading Percentile

$$
\begin{aligned}
& \text { Model: } \text { TEST }_{i}=\alpha_{0}+\beta_{1} \text { YRS_5 }_{i}+\beta_{2} \text { YRS_5-9 } i+\beta_{3} \text { YRS_10 }_{i}{ }_{i}+\theta_{1} \text { PCT }_{-} \text {IMMIG }_{j}+ \\
& \theta_{2}(\text { PCT_IMM*YRS_5 }<)_{i, j}+ \\
& \theta_{3}\left(\mathbf{P C T} \_I M M * Y R S \_5-9\right)_{i, j}+\theta_{4}\left(\mathbf{P C T} \_I M M * Y R S \_10^{+}\right)_{i, j}+ \\
& \mathbf{X}_{i} \delta+\operatorname{KIDNAT}_{i} \lambda+\mathbf{S C}_{i} \gamma+\varepsilon_{i}
\end{aligned}
$$

\begin{tabular}{|c|c|c|c|c|c|c|c|c|c|}
\hline \multicolumn{10}{|c|}{ Miami Sample } \\
\hline Explanatory Variables & \multicolumn{3}{|c|}{ (1) } & \multicolumn{3}{|c|}{ (2) } & \multicolumn{3}{|c|}{ (3) } \\
\hline Intercept & 87.375 & $* * *$ & $(12.49)$ & 87.489 & $* * *$ & $(12.57)$ & 92.712 & $* * *$ & $(13.67)$ \\
\hline Less than 5 Yrs & -86.926 & $* *$ & $(39.56)$ & -85.702 & $* *$ & $(39.08)$ & -91.303 & $* *$ & $(38.78)$ \\
\hline Between 5-9 Yrs & -14.385 & $* * *$ & $(4.948)$ & -13.611 & $* * *$ & $(4.919)$ & -12.398 & $* * *$ & $(4.893)$ \\
\hline 10 or more Yrs & -2.9835 & & $(4.788)$ & -2.5593 & & $(4.739)$ & -1.7161 & & $(4.706)$ \\
\hline Pct. Recent Immig. Kids & -0.2698 & $* *$ & $(0.117)$ & -0.2029 & $*$ & $(0.116)$ & 0.1629 & & $(0.133)$ \\
\hline$(\% \text { Recent Immig) })^{*}(<5$ Yrs $)$ & 2.6547 & $* *$ & $(1.365)$ & 2.6779 & $* *$ & $(1.349)$ & 2.7525 & $* *$ & $(1.340)$ \\
\hline$(\%$ Recent Immig)*(5-9 Yrs) & 0.3845 & $* *$ & $(0.193)$ & 0.4125 & $* *$ & $(0.192)$ & 0.3736 & $* *$ & $(0.191)$ \\
\hline $\begin{array}{l}\text { (\%Recent Immig)*(10+ } \\
\text { Yrs) }\end{array}$ & 0.0341 & & $(0.194)$ & 0.0562 & & $(0.192)$ & 0.0340 & & $(0.190)$ \\
\hline Basic Controls $^{\text {a }}$ & \multicolumn{3}{|c|}{ Yes } & \multicolumn{3}{|c|}{ Yes } & \multicolumn{3}{|c|}{ Yes } \\
\hline Nationality Controls ${ }^{\text {b }}$ & \multicolumn{3}{|c|}{ No } & \multicolumn{3}{|c|}{ Yes } & \multicolumn{3}{|c|}{ Yes } \\
\hline Schools Controls ${ }^{\text {c }}$ & \multicolumn{3}{|c|}{ No } & \multicolumn{3}{|c|}{ No } & \multicolumn{3}{|c|}{ Yes } \\
\hline Pupil/Teacher Ratio & \multicolumn{3}{|c|}{--} & \multicolumn{3}{|c|}{--} & 0.1836 & & $(0.257)$ \\
\hline$\%$ Subsidized Lunch Meals & \multicolumn{3}{|c|}{--} & \multicolumn{3}{|c|}{--} & -0.1683 & $* * *$ & $(0.037)$ \\
\hline School Population & \multicolumn{3}{|c|}{--} & \multicolumn{3}{|c|}{--} & -0.0033 & $* * *$ & $(0.001)$ \\
\hline Inner-city & \multicolumn{3}{|c|}{--} & \multicolumn{3}{|c|}{--} & -2.9788 & $* *$ & $(1.243)$ \\
\hline $\begin{array}{l}\text { F-statistics: }:^{\#} \text { Slope Effects, } \\
F^{c}>F^{*}\end{array}$ & \multicolumn{3}{|c|}{$\mathrm{F}_{(3,2221)}{ }^{\mathrm{c}}=2.60$} & \multicolumn{3}{|c|}{$\mathrm{F}_{(3,2213)}{ }^{\mathrm{c}}=2.84$} & \multicolumn{3}{|c|}{$\mathrm{F}_{(3,2209)}{ }^{\mathrm{c}}=2.69$} \\
\hline $\begin{array}{l}\text { F-statistics: }{ }^{\#} \text { Level Effects, } \\
\mathrm{F}^{\mathrm{c}}>\mathrm{F}^{*}\end{array}$ & \multicolumn{3}{|c|}{$\mathrm{F}_{(4,2221)}{ }^{\mathrm{c}}=2.76$} & \multicolumn{3}{|c|}{$\mathrm{F}_{(4,2213)}{ }^{\mathrm{c}}=2.30$} & \multicolumn{3}{|c|}{$\mathrm{F}_{(4,2209)}{ }^{\mathrm{c}}=3.86$} \\
\hline No. Observations & \multicolumn{3}{|l|}{2240} & \multicolumn{3}{|l|}{2240} & \multicolumn{3}{|l|}{2240} \\
\hline Adjusted $\mathrm{R}^{2}$ & \multicolumn{3}{|l|}{0.1028} & 0.1250 & & & 0.1405 & & \\
\hline $\begin{array}{l}\text { Notes: The reference category is } \\
\text { level. a Basic controls include the } \\
\text { are listed in Table } 1 \text {, the omitted } \\
\text { Canada. . }{ }^{\mathrm{c}} \text { School controls are list } \\
\text { Statistical significance of the F-s } \\
\mathrm{F}_{(4, \infty)}{ }^{*}(0.05)=2.37, \mathrm{~F}_{(4, \infty)} *(0.10)=1 \text {. } \\
\text { Source: Children of Immigrants L }\end{array}$ & $\begin{array}{l}\mathrm{d} \text { in Table } 3 \mathrm{~B} \\
\text { tistic at the }\end{array}$ & $\begin{array}{l}\text { oup is " } \\
\text { howev } \\
5 \text {, and }\end{array}$ & $\begin{array}{l}\text { her", which } \\
\text {, the race p } \\
0 \text { percent: }\end{array}$ & $\begin{array}{l}\text { in parenthes } \\
\text { education, } f \\
\text { composed } \\
\text { centage vari } \\
,_{\infty} *(0.01)=3\end{array}$ & $\begin{array}{l}\text { smalle } \\
\text { les have } \\
, F_{(3, \infty)} \text { * }\end{array}$ & $\begin{array}{l}* \text { denotes } \\
\text { ture, and ho } \\
\text { sample si } \\
\text { peen exclud } \\
0.05)=2.60 \text {, }\end{array}$ & $\begin{array}{l}\text { Snificance a } \\
\text { e ownership } \\
\text { s: Middle } \\
\text { from the s } \\
(3, \infty) *(0.10)=\end{array}$ & $\begin{array}{l}1,5, a \\
\text { Nation } \\
t, \text { Afric } \\
\text { school } \\
8, F_{(4, \infty)}\end{array}$ & $\begin{array}{l}10 \text { percent } \\
\text { ity controls } \\
\text { Europe, or } \\
\text { ntrols. } \#, \# \\
.01)=3.32 \text {, }\end{array}$ \\
\hline
\end{tabular}


TABle A3.

OLS ReSUltS FOR THE DEPENDENT VARIABLE: ASAT Standardized Math PERCENTILE

$$
\begin{aligned}
& \text { Model: } \text { ASAT }_{i}=\alpha_{0}+\beta_{1} \text { YRS_5 }_{i}+\beta_{2} \text { YRS_5-9 }{ }_{i}+\beta_{3} \text { YRS_10 }_{i}{ }_{i}+\theta_{1} \text { PCT_IMMIG }_{j}+ \\
& \theta_{2}(\text { PCT_IMM*YRS_5 }<)_{i, j}+
\end{aligned}
$$

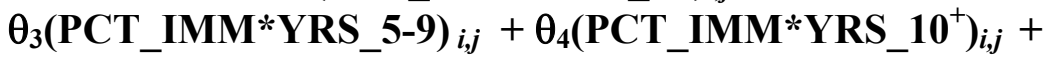

\begin{tabular}{|c|c|c|c|c|c|c|c|c|c|}
\hline \multicolumn{10}{|c|}{ San Diego Sample } \\
\hline \multirow{2}{*}{ Explanatory Variables } & \multicolumn{3}{|c|}{ (1) } & \multicolumn{3}{|c|}{ (2) } & \multicolumn{3}{|c|}{ (3) } \\
\hline & 134.80 & $* * *$ & $(15.61)$ & 145.16 & $* * *$ & $(19.32)$ & 154.16 & $* * *$ & $(22.59)$ \\
\hline Less than 5 Yrs & -1.5794 & & $(8.924)$ & -2.6409 & & $(8.562)$ & -2.8725 & & $(8.588)$ \\
\hline Between 5-9 Yrs & 0.1200 & & $(5.648)$ & 3.1536 & & (5.439) & 2.7729 & & $(5.436)$ \\
\hline 10 or more Yrs & 3.2597 & & (4.949) & 6.0101 & & $(4.750)$ & 5.4398 & & $(4.751)$ \\
\hline Pct. Recent Immig. Kids & -0.2877 & $* * *$ & $(0.106)$ & -0.1684 & & $(0.104)$ & -0.0915 & & $(0.135)$ \\
\hline$(\%$ Recent Immig) $*(<5$ Yrs $)$ & 0.0801 & & $(0.243)$ & -0.0709 & & $(0.234)$ & -0.0655 & & $(0.234)$ \\
\hline$(\%$ Recent Immig) $*$ (5-9 Yrs) & 0.1028 & & $(0.163)$ & -0.1694 & & $(0.159)$ & -0.1547 & & $(0.159)$ \\
\hline $\begin{array}{l}\text { (\%Recent Immig)*(10+ } \\
\text { Yrs) }\end{array}$ & 0.0291 & & $(0.150)$ & -0.2624 & $*$ & $(0.146)$ & -0.2432 & $*$ & $(0.146)$ \\
\hline Basic Controls $^{\text {a }}$ & & Yes & & & Yes & & & Yes & \\
\hline Nationality Controls ${ }^{b}$ & & No & & & Yes & & & Yes & \\
\hline Schools Controls ${ }^{c}$ & & No & & & No & & & Yes & \\
\hline Pupil/Teacher Ratio & & -- & & & -- & & -0.3582 & $*$ & $(0.456)$ \\
\hline$\%$ Subsidized Lunch Meals & & -- & & & -- & & -0.1147 & & $(0.094)$ \\
\hline School Population & & -- & & & -- & & 0.0005 & & $(0.001)$ \\
\hline Inner-city & & -- & & & -- & & -0.6541 & & $(5.254)$ \\
\hline $\begin{array}{l}\text { F-statistics:" } \text { Slope Effects, } \\
\mathrm{F}^{\mathrm{C}}>\mathrm{F}^{*}\end{array}$ & & $2035)^{c}=($ & & & $227)^{c}=1$ & & & $2023)^{c}=0$ & \\
\hline $\begin{array}{l}\text { F-statistics: "\# Level Effects, } \\
\mathrm{F}^{\mathrm{c}}>\mathrm{F}^{*}\end{array}$ & & $2035)^{c}=?$ & & & $027)^{c}=5$ & & & $2023)^{c}=1$ & \\
\hline No. Observations & 2054 & & & 2156 & & & 2054 & & \\
\hline Adjusted $\mathrm{R}^{2}$ & 0.1576 & & & 0.2291 & & & 0.2425 & & \\
\hline $\begin{array}{l}\text { Notes: The reference category is } \\
\text { level. }{ }^{a} \text { Basic controls include the } \\
\text { are listed in Table } 1 \text {, the omitted } \\
\text { Canada. . }{ }^{\circ} \text { School controls are list } \\
\text { Statistical significance of the F-s } \\
\mathrm{F}_{(4, \infty)}{ }^{*}(0.05)=2.37, \mathrm{~F}_{(4, \infty)}{ }^{*}(0.10)=1 .\end{array}$ & $\begin{array}{l}\text { S-born chilc } \\
\text { llowing vari } \\
\text { omparison } g \\
\text { in Table } 3 \mathrm{f} \\
\text { tistic at the } \\
\end{array}$ & 5 , and & $\begin{array}{l}\text { the race } 1 \\
0 \text { percent: }\end{array}$ & $\begin{array}{l}\text { in parenthes } \\
\text { education, } \\
\text { composed } \\
\text { centage vari } \\
\infty)^{*}(0.01)=3\end{array}$ & $\begin{array}{l}\text { es hav } \\
\mathrm{F}_{(3, \infty)}\end{array}$ & $.05)=2.60$ & $\begin{array}{l}\text { nificance a } \\
\text { e ownershi] } \\
\text { s: Middle } \\
\text { from the s } \\
(3, \infty) *(0.10)=\end{array}$ & $\begin{array}{l}\text { e } 1,5, \\
\text { b Nati } \\
\text { st, Afr } \\
\text { f scho } \\
8, F_{(4,}\end{array}$ & $\begin{array}{l}10 \text { percent } \\
\text { y controls } \\
\text { Europe, or } \\
\text { ntrols. } \\
.01)=3.32,\end{array}$ \\
\hline
\end{tabular}

$$
\begin{aligned}
& \mathbf{X}_{i} \delta+\operatorname{KIDNAT}_{i} \lambda+\operatorname{SC}_{i} \gamma+\varepsilon_{i}
\end{aligned}
$$


TABle A4. OLS Results fOR THE DePendent VARIABLE: ASAT STANDardized Math Percentile

$$
\begin{aligned}
& \text { Model: } \text { ASAT }_{i}=\alpha_{0}+\beta_{1} \text { YRS_5 }_{i}+\beta_{2} \text { YRS_5-9 }{ }_{i}+\beta_{3} \text { YRS_10 }_{i}{ }_{i}+\theta_{1} \text { PCT_IMMIG }{ }_{j}+ \\
& \theta_{2}(\text { PCT_IMMXYRS_5 }<)_{i, j}+
\end{aligned}
$$

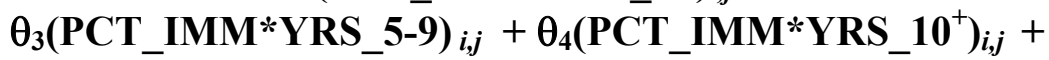

\begin{tabular}{|c|c|c|c|c|c|c|c|c|c|}
\hline \multicolumn{10}{|c|}{ Miami Sample } \\
\hline Explanatory Variables & \multicolumn{3}{|c|}{ (1) } & \multicolumn{3}{|c|}{ (2) } & \multicolumn{3}{|c|}{ (3) } \\
\hline Intercept & 140.85 & $* * *$ & $(14.18)$ & 142.66 & $* * *$ & $(14.25)$ & 138.31 & $* * *$ & $(15.39)$ \\
\hline Less than 5 Yrs & -105.91 & $* *$ & $(44.95)$ & -107.59 & $* *$ & $(44.34)$ & -124.62 & $* * *$ & $(43.72)$ \\
\hline Between 5-9 Yrs & -7.7341 & & $(5.593)$ & -8.5163 & & $(5.553)$ & -7.7498 & & $(5.489)$ \\
\hline 10 or more Yrs & -2.3110 & & $(5.419)$ & 1.7227 & & $(5.356)$ & 1.1094 & & $(5.284)$ \\
\hline Pct. Recent Immig. Kids & -0.6103 & $* * *$ & $(0.132)$ & -0.5696 & $* * *$ & $(0.131)$ & -0.3645 & $* * *$ & $(0.149)$ \\
\hline$(\%$ Recent Immig) $*(<5$ Yrs $)$ & 3.3078 & $* *$ & $(1.551)$ & 3.4199 & $* *$ & $(1.530)$ & 4.0191 & $* * *$ & $(1.510)$ \\
\hline (\%Recent Immig)*(5-9 Yrs) & 0.4086 & $*$ & $(0.217)$ & 0.4227 & $* *$ & $(0.216)$ & 0.4165 & $* *$ & $(0.213)$ \\
\hline $\begin{array}{l}\text { (\%Recent Immig)*(10+ } \\
\text { Yrs) }\end{array}$ & -0.1044 & & $(0.219)$ & -0.0784 & & $(0.217)$ & -0.0315 & & $(0.214)$ \\
\hline Basic Controls $^{\text {a }}$ & \multicolumn{3}{|c|}{ Yes } & \multicolumn{3}{|c|}{ Yes } & \multicolumn{3}{|c|}{ Yes } \\
\hline Nationality Controls ${ }^{b}$ & \multicolumn{3}{|c|}{ No } & \multicolumn{3}{|c|}{ Yes } & \multicolumn{3}{|c|}{ Yes } \\
\hline Schools Controls $^{c}$ & \multicolumn{3}{|c|}{ No } & \multicolumn{3}{|c|}{ No } & \multicolumn{3}{|c|}{ Yes } \\
\hline Pupil/Teacher Ratio & \multicolumn{3}{|c|}{--} & \multicolumn{3}{|c|}{--} & 0.7128 & \multirow[t]{2}{*}{$* * *$} & $(0.290)$ \\
\hline$\%$ Subsidized Lunch Meals & \multicolumn{3}{|c|}{--} & \multicolumn{3}{|c|}{--} & -0.0398 & & $(0.042)$ \\
\hline School Population & \multicolumn{3}{|c|}{--} & \multicolumn{3}{|c|}{--} & -0.0026 & $* *$ & $(0.001)$ \\
\hline Inner-city & \multicolumn{3}{|c|}{--} & \multicolumn{3}{|c|}{--} & -10.528 & $* * *$ & $(1.401)$ \\
\hline $\begin{array}{l}\text { F-statistics: }:^{\#} \text { Slope Effects, } \\
\mathrm{F}^{\mathrm{c}}>\mathrm{F}^{*}\end{array}$ & \multicolumn{3}{|c|}{$\mathrm{F}_{(3,2226)}{ }^{\mathrm{c}}=3.12$} & \multicolumn{3}{|c|}{$\left.\mathrm{F}_{(3,2118)}\right)^{\mathrm{c}}=3.29$} & \multicolumn{3}{|c|}{$\mathrm{F}_{(3,2214)}{ }^{\mathrm{c}}=3.79$} \\
\hline $\begin{array}{l}\text { F-statistics: }:^{\#} \text { Level Effects, } \\
\mathrm{F}^{\mathrm{c}}>\mathrm{F}^{*}\end{array}$ & \multicolumn{3}{|c|}{$\mathrm{F}_{(4,2226)}{ }^{\mathrm{c}}=10.14$} & \multicolumn{3}{|c|}{$\mathrm{F}_{(4,2118)}{ }^{\mathrm{c}}=8.82$} & \multicolumn{3}{|c|}{$\mathrm{F}_{(4,2214)}{ }^{\mathrm{c}}=3.96$} \\
\hline No. Observations & \multicolumn{3}{|l|}{2245} & \multicolumn{3}{|l|}{2245} & \multicolumn{3}{|l|}{2245} \\
\hline Adjusted $\mathrm{R}^{2}$ & \multicolumn{3}{|l|}{0.1044} & 0.1289 & & & 0.1556 & & \\
\hline $\begin{array}{l}\text { Notes: The reference category is } \\
\text { level. }{ }^{a} \text { Basic controls include the } \\
\text { are listed in Table } 1 \text {, the omitted } \\
\text { Canada. . ' School controls are list } \\
\text { Statistical significance of the F-s } \\
\mathrm{F}_{(4, \infty)} *(0.05)=2.37, \mathrm{~F}_{(4, \infty)} *(0.10)=1 \text {. }\end{array}$ & $\begin{array}{l}\text { din Table } 3 \mathrm{E} \\
\text { tistic at the }\end{array}$ & $\begin{array}{l}\text { oup is } \\
\text { howe } \\
5 \text {, anc }\end{array}$ & $\begin{array}{l}\text { her", which } \\
\text {, the race } p \\
0 \text { percent: }\end{array}$ & $\begin{array}{l}\text { in parenthes } \\
\text { education, } \mathrm{f} \\
\text { composed } \\
\text { centage vari } \\
*(0.01)=3\end{array}$ & $\begin{array}{l}\text { smalle } \\
\text { es have } \\
, F_{(3, \infty)} *\end{array}$ & $\begin{array}{l}\text { ure, and ho } \\
\text { sample si } \\
\text { een exclud } \\
0.05)=2.60\end{array}$ & $\begin{array}{l}\text { gnificance at } \\
\text { le ownership } \\
\text { es: Middle } \\
\text { from the se } \\
(3, \infty) *(0.10)=\end{array}$ & $\begin{array}{l}1,5, \mathrm{a} \\
\mathrm{b} \text { Nation } \\
\text { t, Afric } \\
\text { f school } \\
8, \mathrm{~F}_{(4, \infty)}\end{array}$ & $\begin{array}{l}10 \text { percent } \\
\text { ity controls } \\
\text { Europe, or } \\
\text { ontrols. \#,\#\# } \\
0.01)=3.32 \text {, }\end{array}$ \\
\hline
\end{tabular}

$$
\begin{aligned}
& \mathbf{X}_{i} \delta+\operatorname{KIDNAT}_{i} \lambda+\mathbf{S C}_{i} \gamma+\varepsilon_{i}
\end{aligned}
$$


TABLE A5.

SAMPle Sizes for Miami ANd SAN Diego

\begin{tabular}{|c|c|c|c|c|c|c|}
\hline & \multicolumn{3}{|c|}{ Miami } & \multicolumn{3}{|c|}{ San Diego } \\
\hline & $\begin{array}{c}\text { All } \\
\text { Schools }\end{array}$ & $\begin{array}{l}\text { Enclave } \\
\text { Schools }\end{array}$ & $\begin{array}{c}\text { Non-Enclave } \\
\text { Schools }\end{array}$ & $\begin{array}{c}\text { All } \\
\text { Schools }\end{array}$ & $\begin{array}{l}\text { Enclave } \\
\text { Schools }\end{array}$ & $\begin{array}{c}\text { Non-Enclave } \\
\text { Schools }\end{array}$ \\
\hline No. Observations & 2233 & 1284 & 949 & 2027 & 831 & 1196 \\
\hline Born in US & 1091 & 535 & 556 & 882 & 258 & 624 \\
\hline No. Yrs 10 plus in US & 601 & 381 & 220 & 611 & 282 & 329 \\
\hline No. Yrs 5-9 in US & 533 & 366 & 167 & 418 & 225 & 193 \\
\hline No. Yrs 1-4 in US & 7 & 2 & 5 & 116 & 66 & 50 \\
\hline No. Yrs 1-4 in US & 7 & 2 & 5 & 116 & 66 & 50 \\
\hline Mean Mom Education & 12.40 & 13.00 & 12.16 & 11.01 & 10.06 & 12.28 \\
\hline Mean Dad Education & 12.88 & 13.00 & 12.83 & 12.04 & 11.02 & 13.40 \\
\hline Reading \% Score & 25.57 & 60.00 & 11.80 & 17.91 & 13.92 & 23.18 \\
\hline Math \% Score & 34.42 & 73.00 & 19.00 & 45.12 & 42.62 & 48.42 \\
\hline No. Yrs 5-9 in US & 533 & 366 & 167 & 418 & 225 & 193 \\
\hline Mean Mom Education & 12.07 & 12.06 & 12.07 & 10.70 & 9.94 & 11.58 \\
\hline Mean Dad Education & 12.45 & 12.25 & 12.89 & 11.58 & 10.92 & 12.34 \\
\hline Reading \% Score & 38.56 & 37.65 & 40.62 & 29.43 & 23.61 & 36.21 \\
\hline Math \% Score & 55.60 & 54.37 & 58.29 & 45.91 & 43.06 & 49.23 \\
\hline No. Yrs 10 plus in US & 601 & 381 & 220 & 611 & 282 & 329 \\
\hline Mean Mom Education & 12.04 & 11.88 & 12.30 & 10.92 & 10.31 & 11.43 \\
\hline Mean Dad Education & 12.28 & 11.89 & 12.94 & 11.67 & 11.21 & 12.06 \\
\hline Reading \% Score & 41.66 & 39.17 & 45.96 & 37.94 & 33.20 & 41.99 \\
\hline Math \% Score & 54.31 & 51.29 & 59.54 & 48.98 & 47.04 & 50.64 \\
\hline Born in US & 1091 & 535 & 556 & 882 & 258 & 624 \\
\hline Mean Mom Education & 12.24 & 11.55 & 12.90 & 11.60 & 11.02 & 11.84 \\
\hline Mean Dad Education & 12.28 & 11.56 & 12.96 & 12.01 & 11.67 & 12.15 \\
\hline Reading \% Score & 46.48 & 43.40 & 49.45 & 43.62 & 38.62 & 45.69 \\
\hline Math \% Score & 58.07 & 52.81 & 63.13 & 49.77 & 45.06 & 51.72 \\
\hline
\end{tabular}

Source: Children of Immigrants Longitudinal Study (CILS) 1992, Wave T1. 